\title{
Dopamine D1-like Receptors Regulate Constitutive, $\mu$-Opioid Receptor-Mediated Repression of Use-Dependent Synaptic Plasticity in Dorsal Horn Neurons: More Harm than Good?
}

\author{
¿ Zigor Aira, ${ }^{1}$ Teresa Barrenetxea, ${ }^{1}$ Itsaso Buesa, ${ }^{1}{ }^{\circledR}$ Gontzal García del Caño, ${ }^{2}$ and $\oplus^{-J o n ~ J a t s u ~ A z k u e ~}{ }^{1}$ \\ ${ }^{1}$ Department of Neurosciences, School of Medicine and Dentistry, University of the Basque Country UPV/EHU, 48940 Leioa, Bizkaia, Spain, and \\ ${ }^{2}$ Department of Neurosciences, Faculty of Pharmacy, University of the Basque Country UPV/EHU, 01080 Vitoria-Gasteiz, Araba, Spain
}

The current study reports on a synaptic mechanism through which D1-like receptors (D1LRs) modulate spinal nociception and plasticity by regulating activation of the $\mu$-opioid receptor (MOR).

D1LR stimulation with agonist SKF 38393 concentration-dependently depressed C-fiber-evoked potentials in rats receiving spinal nerve ligation (SNL), but not in uninjured rats. Depression was prevented by MOR- but not GABA-receptor blockade. Neurons expressing the D1 subtype were immunopositive for met-enkephalin and vesicular glutamate transporter VGLUT2, but not for GABAergic marker vGAT.

Nerve ligation was followed by increased immunoreactivity for D1 in synaptic compartment (P3) in dorsal horn homogenates and presynaptic met-enkephalin-containing boutons. SNL led to increased immunoreactivity for met-enkephalin in dorsal horn homogenates, which was dose-dependently attenuated by selective D1LR antagonist SCH 23390. During blockade of either D1R or MOR, lowfrequency $(0.2$ or $3 \mathrm{~Hz})$ stimulation (LFS) to the sciatic nerve induced long-term potentiation (LTP) of C-fiber-evoked potentials, revealing a constituent role of both receptors in repressing afferent-induced synaptic plasticity. LFS consistently induced NMDA receptor-dependent LTP in nerve-injured rats. The ability of MOR both to prevent LTP and to modulate mechanical and thermal pain thresholds in behavioral tests was preserved in nerve-ligated rats that were postoperatively treated with SCH 23390. D1LR priming for 30 min sufficed to disrupt MOR function in otherwise naive rats via a mechanism involving receptor overuse.

The current data support that, whereas D1LR-modulated MOR activation is instrumental in antinociception and endogenous repression of synaptic plasticity, this mechanism deteriorates rapidly by sustained use, generating increased vulnerability to afferent input.

Key words: electrophysiology; immunocytochemistry; LTP; nerve injury; nociception; spinal cord

Significance Statement

The current study shows that dopamine D1-like receptors (D1LRs) and $\mu$-opioid receptors (MOR) in the spinal dorsal horn constitutively repress the expression of synaptic long-term potentiation (LTP) of C-fiber-evoked potentials. Anatomical data are provided supporting that the D1 subtype regulates MOR function by modulating met-enkephalin release. Sustained neuropathic pain induced by spinal nerve ligation is accompanied by D1R and met-enkephalin upregulation, acquired D1LR-mediated antinociception, and a loss of endogenous repression of further synaptic plasticity. We show that the ability of MOR to oppose LTP is rapidly impaired by sustained D1LR activation via a mechanism involving sustained MOR activation.

\section{Introduction}

The $\mu$-opioid receptor (MOR) is a major effector in endogenous pain modulation, as well as the primary target of clinically used

Received June 29, 2015; revised April 11, 2016; accepted April 11, 2016.

Author contributions:Z.A. and J.J.A. designed research;Z.A., T.B., I.B., and G.G.d.C. performed research;Z.A., T.B., I.B., and G.G.d.C. analyzed data; Z.A. and J.J.A. wrote the paper.

Supported by the Government of the Basque Country (IT782-13), by the Spanish Government (SAF2013-44533-

P), and by the University of the Basque Country (Ayudas para la Especialización de Personal Investigador, to Zigor opioid analgesics. The development of tolerance or decreased responsiveness to MOR agonists following repeated treatments poses a major limitation to the use of opioid analgesics for the treatment of human chronic pain (Christie, 2008; Williams et al., 
2013). Although prolonged exposure to opioid drugs agonists is a widely recognized determinant of tolerance, several lines of evidence suggest that neuroplastic changes underlying central sensitization also may negatively condition MOR function. For instance, cellular signaling pathways underlying central sensitization in dorsal horn neurons, such as those mediated by the NMDA receptor or protein kinase C (PKC), have been implicated in opioid tolerance (Mao, 1999; Mao and Mayer, 2001; Joseph and Levine, 2010). In addition, prolonged use of opioid drugs has been linked both to chronification of acute or sporadic pain (Wilkinson et al., 2001; Bigal and Lipton, 2009) and opioidinduced hyperalgesia (Chu et al., 2008; Hay et al., 2009).

A relatively unexplored mechanism impinging upon MOR function is the activity of descending pathways during central sensitization and sustained pain. Descending pathways exert both facilitatory and inhibitory control over centripetal progression of nociceptive signals through the dorsal horn and are currently known to play a critical role in generating and maintaining pathologic pain in animal models (Kovelowski et al., 2000; Ossipov et al., 2000; Burgess et al., 2002). Our recent work has shown that plasticity of descending spinopetal noradrenergic, serotonergic, and dopaminergic systems during sustained pain profoundly alters spinal opioidergic neurotransmission (Aira et al., 2012, 2014, 2015).

The dopamine receptor family comprises five distinct G-protein-coupled receptors, viz. D1 through D5, that fall into two classes on the basis of their biochemical and pharmacological properties. Whereas D1-like receptors (D1LRs), including D1 and D5, activate the heterotrimeric proteins $\mathrm{G} \alpha$ s and G $\alpha$ olf and are positively coupled to activation of adenylyl cyclase (AC) and protein kinase A (PKA), the members of the D2-like subfamily (D2-D4) are linked to activation of $\mathrm{G} \alpha \mathrm{i}$ and $\mathrm{G} \alpha$ o proteins and are negatively coupled to AC and PKA (Neve et al., 2004; Beaulieu and Gainetdinov, 2011). All five receptors have been found in the spinal cord (Dubois et al., 1986; Schambra et al., 1994; Yokoyama et al., 1994; van Dijken et al., 1996; Levant and McCarson, 2001; Zhao et al., 2007; Zhu et al., 2007; Charbit et al., 2009). Dopaminergic innervation of the spinal dorsal horn is provided by diencephalo-spinal neurons originating in the hypothalamic A11 cell group (Hökfelt et al., 1979; Skagerberg and Lindvall, 1985; Qu et al., 2006; Barraud et al., 2010), and projections arising from these neurons inhibit nociceptive transmission at the dorsal horn level, mainly via D2 receptors (Fleetwood-Walker et al., 1988; Tamae et al., 2005; Charbit et al., 2009; Lapirot et al., 2011; Taniguchi et al., 2011). Recently, we reported that dopaminergic modulation of spinal nociception via receptors of the D2 subtype is upregulated during sustained neuropathic pain, resulting in dramatic enhancement of MOR-mediated antinociception (Aira et al., 2014). Although data regarding a potential role of D1LRs in modulating spinal nociception is scarce, the available evidence suggests an involvement of the receptor in mechanisms related with central sensitization rather than in direct modulation of pain (Yang et al., 2005; Munro, 2007), and recent evidence suggests that dopaminergic neurotransmission mediated by D1LRs may critically participate in consolidation of neural plastic changes triggered by inflammatory pain (Kim et al., 2015).

The current study was undertaken to explore the influence of dopaminergic neurotransmission mediated by D1LRs in MOR

Correspondence should be addressed to Dr Jon Jatsu Azkue, University of the Basque Country UPV/EHU, 48940 Leioa, Bizkaia, Spain. E-mail: jonjatsu.azkue@ehu.eus.

DOI:10.1523/JNEUROSCI.2469-15.2016

Copyright $\odot 2016$ the authors $\quad 0270-6474 / 16 / 365662-13 \$ 15.00 / 0$ function in several distinct contexts of central nociception, including afferent excitation by single noxious stimuli, synaptic plasticity induced by repetitive noxious stimulation, and sustained neuropathic pain following nerve injury. We used electrophysiological techniques and behavioral assessment procedures to evaluate MOR function, whereas neuroanatomical and quantitative aspects of receptor expression were addressed by using confocal immunofluorescence and biochemical methods.

\section{Materials and Methods}

Animal experiments were performed according to the European Communities Council Directive (86/609/ECC) on adult male Sprague Dawley rats $(250-350 \mathrm{~g})$. The protocols for animal care and use were approved by the appropriate committee at the University of the Basque Country.

Spinal nerve ligation surgery. The left spinal L5 nerve root was ligated under $4 \%$ chloral hydrate anesthesia $(0.4 \mathrm{~g} / \mathrm{kg}$, i.p.), as previously described by Kim and Chung (1992). After surgery, the animals were allocated to individual cages to recover, with food and water available ad libitum. Sham-operated animals received no nerve ligation, being otherwise identically prepared and assessed. Successful nerve ligation was confirmed by decreased mechanical paw withdrawal thresholds.

Electrophysiology. Procedures were performed under urethane anesthesia $(1.5 \mathrm{~g} / \mathrm{kg}$, i.p.). A tracheotomy was performed to maintain an open, low-resistance airway, and cannulae were inserted into the left common carotid artery and the right internal jugular vein for arterial blood pressure monitoring (mean $80-100 \mathrm{mmHg}$ ) and continuous infusion of Tyrode's solution (in mM: $137 \mathrm{NaCl}, 2.7 \mathrm{KCl}, 1.4 \mathrm{CaCl}_{2}, 1 \mathrm{MgCl}_{2}, 6$ $\left.\mathrm{NaHCO}_{3}, 2.1 \mathrm{NaH}_{2} \mathrm{PO}_{4}, \mathrm{pH} 7.4\right)$ at $0.8-1 \mathrm{ml} / \mathrm{h}$, respectively. Colorectal temperature was continuously monitored and euthermia $\left(37^{\circ}-38^{\circ} \mathrm{C}\right)$ was maintained via a feedback-controlled underbody heating pad for the duration of the experimental procedure. The left sciatic nerve was exposed, gently freed from connective tissue, and placed onto platinum hook electrodes for bipolar electrical stimulation. Bilateral dorsal laminectomies were performed at vertebrae T13-L1, the vertebral column was immobilized to a rigid frame, and the dura mater overlaying lumbosacral spinal segments was carefully removed.

Electrophysiological setup was essentially as described previously (Azkue et al., 2003). Tungsten microelectrodes $(5 \mathrm{M} \Omega$ ) were placed into laminae I-II (100-300 $\mu \mathrm{m}$ deep and $1 \mathrm{~mm}$ lateral to the spinal mid-line). The position of the tip of the recording electrode in the spinal cord was marked with a small electrolytic lesion by delivery of an anodal current through the recording electrode (50 $\mu \mathrm{A}$ anodal current for $10 \mathrm{~s})$ and histologically verified. Single monophasic, square-wave electrical pulses were delivered as test stimuli to the sciatic nerve trunk at a midthigh level on a per-minute basis by means of a current-controlled stimulus isolator, and the elicited spinal field potentials were amplified (analog bandpass set at $1-550 \mathrm{~Hz}$ ), displayed on an oscilloscope, and digitized at $10 \mathrm{kS} / \mathrm{s}$ and 12-bit resolution (PCI-MIO-16E acquisition card, National Instruments). Field potentials were evoked in superficial laminae of the spinal dorsal horn by suprathreshold, electrical C-fiber stimulation $(3-3.5 \mathrm{~mA}$ pulses of $0.5 \mathrm{~ms}$ duration) and quantified as described previously (Buesa et al., 2006). Electrical stimulation of the sciatic nerve trunk did not permit us to discern the relative contribution of cutaneous, muscle and joint fibers to the recorded signals.

In experiments administering drugs via spinal superfusion (cf. below), each drug concentration change lasted for $20 \mathrm{~min}$, and only the last 10 evoked field potentials were extracted for analysis from the baseline control period and from each treatment period. The areas of field potentials evoked during each treatment period were compared with those recorded during a control, artificial CSF (aCSF) superfusion period, by using univariant ANOVA and post hoc Bonferroni's or Tamhane's multiple-comparison tests.

In experiments aimed at inducing long-term potentiation (LTP) of C-fiber-evoked field potentials, conditioning low-frequency stimulation (LFS) consisted of two $30 \mathrm{~s}$ trains of $3 \mathrm{~mA}$ pulses of $1.5 \mathrm{~ms}$ duration at either 0.2 or $3 \mathrm{~Hz}, 30 \mathrm{~s}$ apart.

Drug preparation and delivery. Drugs used included D-AP5 (NMDA receptor antagonist), SCH 23390 (D1R antagonist), SKF 38393 (D1R 
agonist), [D-Ala2, N-MePhe4, Gly-ol]-enkephalin (DAMGO; MOR agonist), D-Phe-c[Cys-Tyr-D-Trp-Orn-Thr-Pen]-Thr-NH2 (CTOP; MOR antagonist), and [R-(R,S)]-6-(5,6,7,8-Tetrahydro-6-methyl-1, 3-dioxolo[4,5-g] isoquinolin-5-yl)furo[3,4-e]-1,3-benzodioxol-8 $(6 \mathrm{H})$ one (bicuculline; GABAA receptor antagonist), all six from Tocris Bioscience. Stock solutions were obtained by diluting drug powder in double-distilled water, and working solutions were prepared in aCSF (in mm: $130 \mathrm{NaCl}, 3.5 \mathrm{KCl}, 1.25 \mathrm{NaH}_{2} \mathrm{PO}_{4}, 24 \mathrm{NaHCO}_{3}, 1.2 \mathrm{CaCl}_{2}, 1.2$ $\mathrm{MgSO}_{4}, 10 \mathrm{D}-( \pm)$ glucose, $\left.\mathrm{pH} 7.4\right)$ immediately before delivery. For spinal administration, drugs were applied in small volumes $(10-15 \mu \mathrm{l})$ by controlled superfusion via a silicone, $40-50 \mathrm{~mm}^{2}$ pool attached to the dorsal surface of the spinal cord (Beck et al., 1995).

To measure the ability of D1LRs to modulate C-fiber-evoked spinal field potentials, these were recorded during spinal superfusion with successively increasing, cumulative concentrations of D1LR agonist SKF 38393. The effects of SKF 38393 on evoked potentials were D1LRspecific, as confirmed by blockade with D1LR antagonist SCH 23390 (data not shown).

To evaluate the influence of $\mu$-opioid- or GABA-receptor blockade on the effects of SKF 38393 on evoked field potentials, the agonist was administered in combination with subthreshold concentrations of CTOP (100 nM) or bicuculline, respectively. Antagonist concentrations were selected on the basis of preliminary experiments.

For chronic blockade of D1LRs, SCH 23390 was administered intraperitoneally on a daily basis at either 0.5 or $0.05 \mathrm{mg} / \mathrm{kg}$. Intraperitoneally delivered SCH 23390 could depress C-fiber-evoked spinal field potentials (see Fig. 7), which served to confirm a spinal locus of action of $\mathrm{SCH}$ 23390 when using a systemic route of administration.

Subcellular fractionation of spinal cord tissue. Biochemical fractionation of dorsal horn proteins was performed with minor variations according to previous studies (Yang et al., 2009; Cao et al., 2011). Briefly, rats were deeply anesthetized with sodium pentobarbital (50 mg/kg, i.p.) and killed by decapitation. L4-L5 segments were quickly extracted into ice-cold aCSF. Tissue was separated and homogenized mechanically with a motor-driven glass/glass tissue homogenizer in ice-cold lysis buffer ( 10 $\mathrm{mm}$ Tris, $\mathrm{pH}$ 7.6, $320 \mathrm{~mm}$ sucrose, $5 \mathrm{~mm}$ EDTA) containing protease inhibitors (5 mM EGTA, 1 mM PMSF, $10 \mathrm{U} / \mathrm{ml}$ aprotinin, $0.0001 \%$ chymostatin, $0.0001 \%$ leupeptin, and $0.0001 \%$ pepstatin). Dorsal horn samples ipsilateral and contralateral to surgery were taken and processed separately. Homogenates were centrifuged at $1000 \times g$ for $10 \mathrm{~min}$ to remove cell nuclei (P1) from the low supernatant (S1). S1 was collected and centrifuged at $10,000 \times g$ during 15 min to separate a P2 pellet containing the crude synaptosomal fraction and a cytoplasmic fraction S2 with microsomes. The P2 pellet was incubated in the lysis buffer containing $0.5 \%$ Triton and centrifuged at $32,000 \times g$ for $20 \mathrm{~min}$ to obtain the crude synaptic vesicle fraction (S3) and the final pellet containing the synaptic fraction $(\mathrm{P} 3)$. The latter was solubilized in resuspension buffer (10 mM Tris, pH 8.0, 1 mm EDTA, 2\% SDS). All fractions were stored at $80^{\circ} \mathrm{C}$. We have shown previously that only $\mathrm{P} 3$ fraction is enriched with synaptic density proteins, such as postsynaptic density protein PSD-95 (Aira et al., 2013).

Western blot. BCA protein assay kit (Pierce) was used for determining protein concentration. Identical amounts of protein $(50 \mu \mathrm{g}$ of spinal cord subcellular fractions or $20 \mu \mathrm{g}$ HEK293T cell membranes) were loaded to SDS-PAGE using $8 \%$ or $10 \%$ running gels and transferred to nitrocellulose membranes (GE Healthcare). After a blocking step with $5 \%$ nonfat milk in PBST for $1 \mathrm{~h}$ at room temperature, membranes were incubated overnight at $4^{\circ} \mathrm{C}$ with primary antibody. We used an affinitypurified goat polyclonal antibody against D1R (E-16; sc-31479 from Santa Cruz Biotechnology) at 1:1000 and a rabbit polyclonal antibody to met-enkephalin (Millipore) 1:1000 as primary antibodies. The goat polyclonal antibody to D1R was tested for band specificity and no crossreactivity with D5R (the other member of the D1R-like subfamily) in samples from HEK293T cells transfected with either D1R-myc or D5Rmyc (cf. below). Antiserum specificity to met-enkephalin has been documented previously in KO mice (Chen et al., 2008). After incubation with primary antibodies, membranes were washed three times in PBST for $10 \mathrm{~min}$ and incubated with HRP-conjugated donkey anti-goat or donkey anti-rabbit antisera (GE Healthcare) 1:5000 for $1 \mathrm{~h}$ at room tem- perature. Thermo Fisher Scientific SuperSignal Chemiluminescent Substrate was used to detect HRP on the blots. Spectrophotometry was used to determine protein concentration in each sample, and the required volume was then calculated to load the same amount of protein $(50 \mu \mathrm{g})$ to each lane. Reversible validated Ponceau staining was used to check equal loading of gels (Aldridge et al., 2008; Romero-Calvo et al., 2010). For quantitation, protein band densities were analyzed by using NIH ImageJ software. The dorsal horn contralateral to surgery site in sham condition was used as the reference to normalize protein band densities in relative density analyses. Student's $t$ test was used for comparisons.

Immunofluorescence. Deeply anesthetized rats (sodium pentobarbital; $50 \mathrm{mg} / \mathrm{kg}$, i.p.) were perfused transcardially with $250 \mathrm{ml}$ of $0.9 \%$ saline followed by $900 \mathrm{ml}$ of $4 \%$ paraformaldehyde in phosphate buffer (PB; $0.1 \mathrm{M}$ ), pH 7.4. L4-L5 segments were removed, postfixed with $4 \%$ paraformaldehyde in $\mathrm{PB}$ for $4 \mathrm{~h}$, and then cryoprotected for $48 \mathrm{~h}$ with $30 \%$ sucrose in PBS at $4^{\circ} \mathrm{C}$. Coronal, $40-\mu \mathrm{m}$-thick cryotome sections were serially collected in PBS and preincubated with $1 \%$ bovine serum albumin (Sigma-Aldrich) and $1 \%$ normal serum ( $1 \mathrm{~h}$ at $\mathrm{RT}$ ). Paraformaldehyde-fixed spinal cord tissue from wild-type and D1 receptor knock-out (D1R ${ }^{-1-}$ ) mice (Xu et al., 1994) was sectioned in the coronal plane and identically processed throughout as the tissue sections from rat spinal cord. Five primary antibodies were used in triple immunofluorescence experiments, namely rabbit and goat polyclonals to D1R and met-enkephalin as above (at 1:1000 and 1:500, respectively), mouse monoclonals to synaptophysin or vGAT (at 1:1000 or 1:500, respectively; from Sigma-Aldrich and Synaptic Systems, respectively), and a polyclonal antibody raised in guinea pig against vesicular glutamate transporter VGLUT2 (at 1:1000; Synaptic Systems). After preincubations with normal serum of species other than those in which the secondary antibodies were raised, sections were sequentially incubated with Cy5 650-conjugated donkey anti-rabbit, Dylight 549-conjugated donkey anti-mouse, and AlexaFluor 488-conjugated donkey anti-goat fluorescent antibodies (1:200; Jackson ImmunoResearch) and mounted in Mowiol (Vector Laboratories).

Paraformaldehyde-fixed HEK293T cells (either D1R-myc or D5Rmyc transfected) were treated with blocking buffer $(0.066 \%$ saponin, $0.22 \%$ gelatin in PBS, $1 \%$ bovine serum albumin, $1 \%$ normal donkey serum) for $1 \mathrm{~h}$ at RT, followed by incubation at $4^{\circ} \mathrm{C}$ with primary antibodies diluted in blocking buffer: mouse monoclonal against c-myc (1: 1000; clone 9E10, Covance) combined with either goat polyclonal E-16 antibody against D1R (1:500; Santa Cruz Biotechnology) or goat polyclonal R-18 antibody against D5R (1:500; Santa Cruz Biotechnology; sc-1441). Thereafter, cells were incubated for $1 \mathrm{~h}$ at RT in fluorescentconjugated secondary antibodies DyLight 549 donkey anti-mouse $\mathrm{F}\left(\mathrm{ab}^{\prime}\right) 2$ fragment (1:400; Jackson ImmunoResearch) and AlexaFluor 488 donkey anti-goat IgG (1:400; Invitrogen). After extensive washing with PBS containing $0.22 \%$ gelatin and counterstaining with Hoechst 333428 (Sigma-Aldrich) culture coverslips were mounted in Mowiol. Immunolabeled sections and HEK293T cells were viewed in a Fluoview FV500 Olympus confocal microscope, and digital photomicrographs were acquired sequentially to avoid overlapping of fluorescent emission spectra. NIH ImageJ software (Intensity Correlation plug-in; Li et al., 2004) was used to adjust brightness and contrast, to obtain image colocalization overlays, as well as to perform pixel-wise intensity correlation-based analyses of confocal photomicrographs. Pearson's correlation coefficient and Fisher's exact test were used to determine and contrast colocalization values, respectively.

HEK293T cell culture and transfection. Human embryonic kidney 293T (HEK293T) cells obtained from the American Type Culture Collection (ATCC; CRL-3216) were maintained in DMEM (ATCC, 30-2002), supplemented with $10 \%$ fetal bovine serum (Sigma-Aldrich) and antibiotics ( $100 \mathrm{U} / \mathrm{ml}$ penicillin and $100 \mu \mathrm{g} / \mathrm{ml}$ streptomycin; Invitrogen, Life Technologies). Before transfection, cells were plated onto poly-D-lysinecoated $18 \mathrm{~mm}$ glass coverslips (for fluorescence microscopy) or $60 \mathrm{~mm}$ culture dishes (for Western blot analysis). When approaching 50-60\% confluence, the cells were transfected with pCMV6 plasmid (Origene) carrying the coding sequence of C-terminal myc-tagged rat D1R or D5R $\left(1 \mu \mathrm{g} \mathrm{DNA} / \mathrm{cm}^{2}\right)$ using Xfect Transfection Reagent (Clontech, 631317) according to the manufacturer's guidelines. Forty-eight hours after 
transfection, cells were either fixed for $10 \mathrm{~min}$ at RT $4 \%$ phosphate-buffered paraformaldehyde and processed for immunofluorescence, or harvested in ice-cold $750 \mu$ l hypotonic buffer (5 mм Tris- $\mathrm{HCl}, \mathrm{pH} 7.4,1 \mathrm{~mm} \mathrm{MgCl}_{2}, 0.5$ mM phenylmethylsulfonylfluoride, $50 \mu \mathrm{M}$ iodoacetamide) for Western blot analysis. The cell suspension was homogenized by passage through 20 and 21 gauge needles, and then mixed with an equal volume of the same buffer containing $0,64 \mathrm{~m}$ sucrose and centrifuged at $1000 \times g$ during $5 \mathrm{~min}$ to remove cell nuclei and unbroken cells (P1) from the low superna$\operatorname{tant}(\mathrm{S} 1)$. S1 was then collected and centrifuged at $37,000 \times g$ during $15 \mathrm{~min}$ to obtain a P2 pellet enriched in plasma membrane, which was subjected to denaturation and Western blot analysis.

D1R antibody specificity tests. Specificity tests for the goat polyclonal E-16 antibody to D1R were performed in spinal cord sections from mice deficient in D1R, as well as in HEK293T cells transfected with either D1R-myc or D5Rmyc. Sections of paraformaldehyde-fixed spinal cord tissue from wild-type and D1R ${ }^{-/-}$ mice were obtained and immunostained as described above. Immunoreactivity for D1R was found throughout the dorsal horn of wild-type mice, including but not limited to superficial laminae, whereas immunopositive signal was virtually undetectable in spinal cord sections from $\mathrm{D} 1 \mathrm{R}^{-1-}$ mice. This result supported that the antibody could selectively recognize the D1 receptor in paraformaldehyde-fixed tissue (Fig. 1).

Additional tests were performed to discard cross-reactivity with D5R in either immunofluorescence or Western blot analyses. In HEK293T cells cultured and transfected as described above, immunofluorescence for c-myc was detected in every D1R- and D5Rimmunopositive cell, respectively, but not in nontransfected cells. Colocalization of the immunofluorescence signals was virtually complete, showing that both antibodies recognized the same protein pool. In addition, neither D5R- nor D1R-immunoreactivity was detected in D1R-myc and D5R-myc-expressing cells, respectively, demonstrating that there was no cross-reactivity between D5R protein and the D1R-specific antibody or between D1R protein and the D5R-specific antibody. Consistent with these results, no D1R- or D5Rimmunoreactive bands in membranes prepared from nontransfected HEK293T cells, whereas antibodies to D1R or D5R produced immunopositive bands only in membranes from cells transfected with D1Rmyc or D5R-myc, respectively. Western blot against c-myc revealed that recombinant D1R-myc migrated slightly below D5R-myc, consistent with the calculated mass difference of $3.7 \mathrm{kDa}$. The results thus supported that the antibody selectively recognized the D1 receptor with no cross-reactivity to D5R, the other member of the D1LR subfamily.

Behavioral assessment. For mechanical pain threshold evaluation, we determined 50\% mechanical paw withdrawal thresholds for the left hindpaw to plantar stimulation with von Frey monofilaments (North Coast Medical) according to an up-down algorithm (Chaplan et al., 1994). We assessed thermal pain thresholds on a hotplate device (WPI; Almási et al., 2003). Briefly, rats were placed in a Plexiglas chamber on the plate at $30^{\circ} \mathrm{C}$ for $5 \mathrm{~min}$ for habituation, and plate temperature was raised at a rate of $6^{\circ} \mathrm{C} / \mathrm{min}$ until the animal exhibited paw licking or withdrawal behaviors (cutoff temperature $50^{\circ} \mathrm{C}$ ). The heat pain threshold was calculated as the mean temperature eliciting response from two repeated procedures, 30 $\min$ apart. The evaluator was blind to received treatments. Nonparametric Kruskal-Wallis one-way ANOVA and Mann-Whitney rank test were used to compare thresholds with those before surgery and across time points (SPSS, v15.0).

\section{Results \\ D1LRs depress dorsal horn excitability after nerve injury via MOR}

To evaluate the ability of the spinal D1R to modulate peripheral noxious input to dorsal horn neurons, we first recorded C-fiberevoked field potentials in superficial layers of the dorsal horn during spinal superfusion with D1LR agonist SKF 38393. Administration of the drug failed to alter evoked potentials in uninjured rats (Fig. 2). In nerve-injured rats, however, SKF 38393 significantly and concentration-dependently decreased evoked potentials. Reduction was statistically significant at $1 \mu \mathrm{M}$ drug concentration $(48.18 \pm 0.26 \%$ reduction; $p<0.01 ; n=6)$.

Recent reports have shown interactions of dopaminergic neurotransmission with opioid analgesia (Becker et al., 2001; Aira et al., 2014; Brewer et al., 2014). Here, we explored whether the D1LR-mediated modulation of evoked potentials involved activation of the spinal MOR. Coadministration of the selective MOR antagonist CTOP at subthreshold concentration (100 nM), ie, one not altering evoked potentials per se, completely blocked depression of evoked potentials by $1 \mu \mathrm{M}$ SKF 38393 (Fig. 2). In contrast, SKF 38393-induced depression was unaffected by GABA receptor antagonist bicuculline (100 nM; $45.89 \pm 0.19 \%$ reduction; $p<0.01 ; n=6$ ).

\section{$\mathrm{D} 1 \mathrm{R}$ is expressed in glutamatergic, met-enkephalin- containing neurons}

The endogenous peptide met-enkephalin is abundantly expressed in the spinal dorsal horn (Todd and Spike, 1992; Mar- 


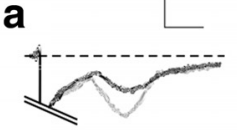

SKF 38393 b

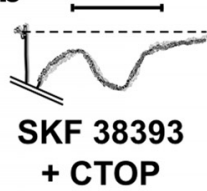

Sham operation + SKF 38393

SNL + SKF 38393

$\triangle \mathrm{SNL}+$ SKF $38393+100 \mathrm{nM}$ CTOP

SNL + SKF $38393+100 \mathrm{nM}$ bicuculline

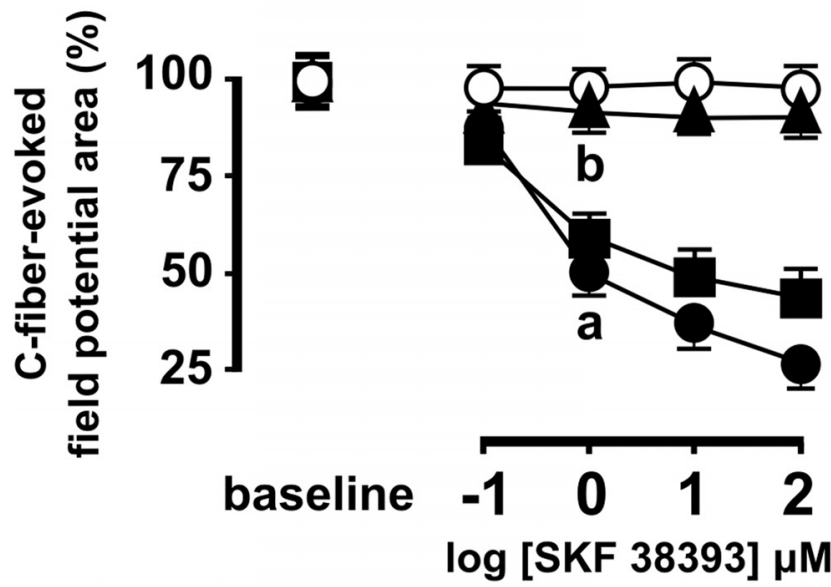

Figure 2. D1R-mediated depression of C-fiber-evoked spinal field potentials after SNL is mediated by MOR. Mean areas of C-fiber-evoked potentials are shown during spinal superfusion with increasing, cumulative concentrations of D1R agonist SKF 38393 either alone or in combination with subthreshold concentrations of $\mu$-opioid antagonist CTOP or bicuculline. SKF 38393 effectively depresses evoked potentials in nerve-injured but not sham-operated rats. D1Rmediated depression is blocked by coadministration of CTOP but not by that of bicuculline. Asterisks indicate statistical significance at $p<0.01$ using the post hoc Bonferroni test following one-way ANOVA, when comparing field potential magnitudes during drug administration to baseline control potentials before drug delivery ( $n=6$ each group; error bars indicate SEM). For clarity, only the earliest statistically significant effects are labeled. Representative recordings shown at the top, gray traces representing baseline potentials, illustrate the effect of $1 \mu \mathrm{m}$ SKF 38393 on (-fiber-evoked field potentials in the absence $(\boldsymbol{a})$ or presence $(\boldsymbol{b})$ of $100 \mathrm{~nm} \mathrm{CTOP}$ (scale, $50 \mathrm{~ms}$ and $200 \mathrm{mV}$; horizontal bar indicates (-fiber latency).

vizón et al., 2009) and presents high affinity for MOR (Delfs et al., 1994; Raynor et al., 1994; Fields, 2004). Based on prior evidence that presynaptic D1R can facilitate neurotransmitter release in the CNS (Cameron and Williams, 1993), we hypothesized that upregulation of D1R might occur in dorsal horn neurons containing met-enkephalin. In addition, available evidence suggests that both glutamatergic and GABAergic neurons in the dorsal horn may contain met-enkephalin (Todd and Spike, 1992; Todd et al., 2003; Marvizón et al., 2007, 2009). By using confocal triple immunofluorescence we found that D1R was expressed in metenkephalin-containing neurons in the dorsal horn also expressing the vesicular glutamate transported VGLUT2 (Fig. 3), but not in neurons containing vGAT, a marker for GABAergic synapses.

Spinal nerve ligation triggers presynaptic upregulation of D1R in met-enkephalin-containing boutons

There is previous evidence that dopamine-enriched contexts may favor D1R expression (Aubert et al., 2005), and that the release of dopamine in the spinal dorsal horn is indeed increased in patho-
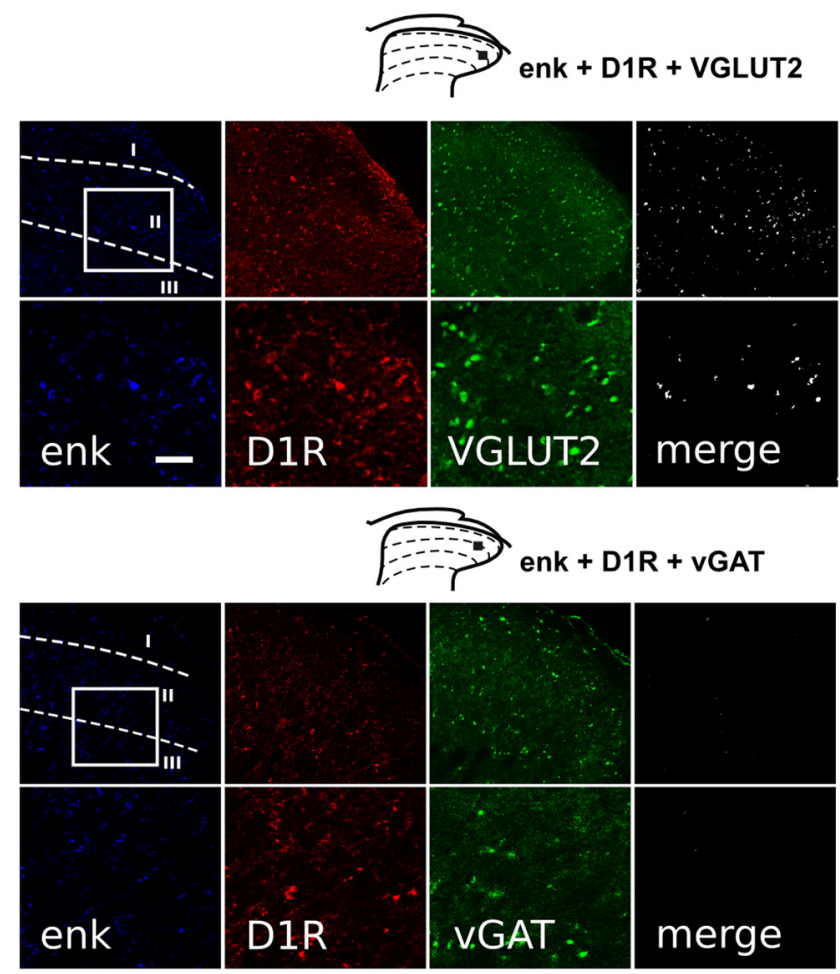

Figure 3. Coexpression of D1R and met-enkephalin occurs in putative glutamatergic, but not GABAergic neurons in superficial laminae of the dorsal horn. Triple immunofluorescent labelings in lumbar histological sections are shown, revealing colocalization of D1R in enkephalinergic neurons also containing the vesicular glutamate transporter VGLUT2, a glutamatergic neuron marker, but not in neurons containing vGAT, a marker of GABAergic terminals. Triple merge channel is shown as white. Insets in low-power micrographs and diagrams at the top indicate the locations of high-power micrographs. Scale bar, $10 \mu \mathrm{m}$.

logic pain (Gao et al., 2001). We assessed whether changes in the modulatory profile of D1R as shown above were accompanied by increased expression of the receptor in dorsal horn neurons. To this end, we assessed D1R expression in dorsal horn homogenates extracted from nerve-injured rats $9 \mathrm{~d}$ after surgery. Western blots showed an increase in D1R-like immunoreactivity in synaptic fraction (P3) on the injury side, but not in cytoplasmic fraction (S2) on either side. Relative density analysis quantified such increase as over fourfold relative to immunoreactivity in $\mathrm{P} 3$ fraction ipsilateral to injury in sham-operated rats $(p<0.01$, Student's $t$ test; Fig. 4).

By using confocal triple immunofluorescence microscopy and synaptophysin as presynaptic marker, we found that presynaptic densities immunopositive to met-enkephalin became highly enriched in D1R after spinal nerve ligation (SNL; Fig. 2). Comparisons of pixel-wise correlations by using the Fisher' exact test confirmed statistically higher correlation levels in nerve-injured rats relative to sham-operated rats $(\operatorname{Rr} 0.73$ vs $0.02 ; z=-75.72$, $p<0.01)$

Sustained, endogenous activation of D1R following SNL increases met-enkephalin levels in the dorsal horn We performed Western blots on homogenates of dorsal horns extracted from nerve-injured and sham-operated rats $9 \mathrm{~d}$ after surgery. We found a dramatic increase in met-enkephalin-like immunoreactivity in the homogenates from nerve-injured rats compared with those from sham-operated controls. As assessed by density analysis, such increase was statistically significant $(p<$ 0.01, Student's $t$ test; Fig. 5). 
A
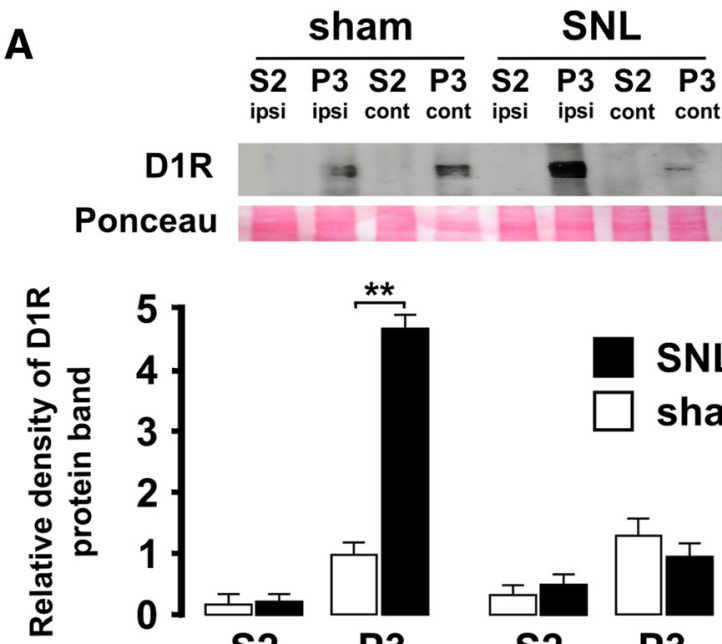

B
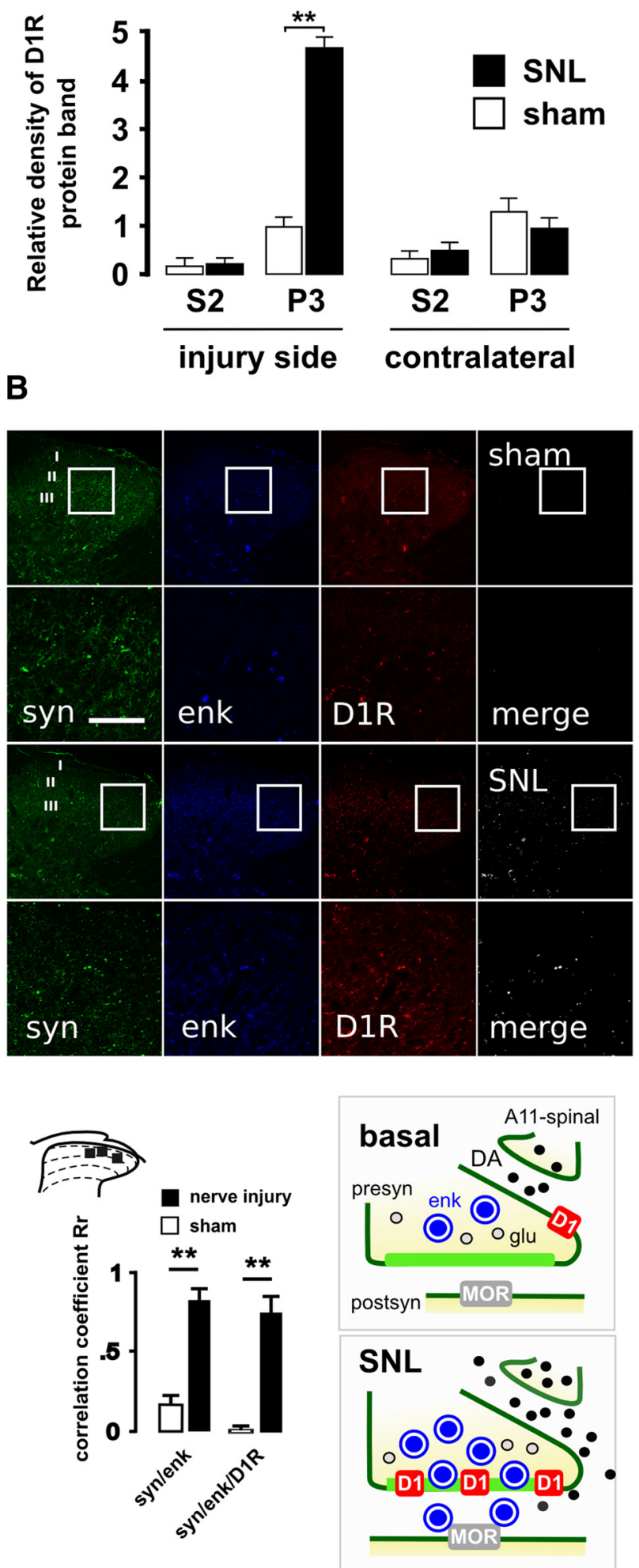

Figure 4. Presynaptic upregulation of D1R and met-enkephalin following spinal nerve ligation. $A$, Western blot of dorsal horn homogenates from nerve-injured and sham-operated rats show increased presence of D1R-like immunoreactivity in synaptic compartment (P3) of the
We next sought to determine whether sustained D1LR activation was required for augmenting met-enkephalin-like immunoreactivity. To this end, we blocked D1LRs by administering daily intraperitoneal injections of the selective D1LR antagonist SCH 23390 during the next $9 \mathrm{~d}$ following nerve injury at either 0.5 or $0.05 \mathrm{mg} / \mathrm{kg}$ in separate groups. We found that chronic D1LR blockade, but not vehicle administration (isotonic saline), dosedependently attenuated the increase in met-enkephalin-like immunoreactivity that ensued after nerve injury. As assessed by density analysis, such attenuation was statistically significant after SCH 23390 treatment at either dose compared with immunoreactivity level in nerve-injured, vehicle-treated rats $(p<0.01$, Student's $t$ test; Fig. 5).

D1LR-regulated recruitment of MOR constitutively represses afferent-induced synaptic plasticity

We applied low-frequency electrical pulses to the sciatic nerve at either 0.2 or $3 \mathrm{~Hz}$ as conditioning input. Both stimulation patterns failed to condition subsequently evoked potentials in naive rats (Fig. 6). However, whenever the spinal MOR system was blocked pharmacologically with CTOP (100 nM), conditioning stimulation at either frequency consistently induced synaptic LTP of C-fiber-evoked dorsal horn potentials (78.11 $\pm 0.53 \%$ increase; $p<0.01$ relative to baseline; Fig. 6$)$. The occurrence of LTP thus exposed a constitutive role of the spinal MOR system in repressing afferent activity-dependent synaptic plasticity in dorsal horn neurons. In subsequent experiments, the ability of conditioning LFS to induce LTP was used as an end-point measure of this repressing function of MOR.

In analogous experiments we blocked the spinal D1LRs instead of MOR. We found that LTP consistently ensued after LFS during D1LR blockade with SCH 23390 (58.42 \pm 0.39\% increase; $p<0.01$; Fig. 6), thus also implicating D1LRs in endogenous mechanisms constitutively repressing use-dependent synaptic plasticity. If D1LRs operate here by regulating the release of endogenous MOR ligand, as supported by the above anatomical and pharmacological data, then blocking D1LR activation should prevent endogenous recruitment of MOR, but not necessarily MOR activation by an exogenous agonist. To test for this, we applied the highly selective MOR agonist DAMGO by spinal superfusion $(100 \mu \mathrm{M}) 2$ min before LFS, during concomitant D1LR

\footnotetext{
$\leftarrow$

dorsal horn on the injury side. Ponceau staining was used to confirm equal protein loading. Bars show image analysis-based D1R band density quantitation normalized to $\mathrm{P} 3$ from uninjured rats. Asterisks indicate statistical significance at $p<0.01$ using Student's $t$ test. Error bars indicate SEM. $\boldsymbol{B}$, Confocal micrographs of the dorsal horns from sham-operated and nerveligated rats showing immunoreactivities for D1R (red channel), met-enkephalin (blue channel), and presynaptic marker synaptophysin (green channel). Insets in low-magnification micrographs at the top row in each condition indicate the locations of high-power (scale bar, $5 \mu \mathrm{m}$ ) micrographs below. The most conspicuous change following experimental nerve injury was a dramatic increase in triple colocalization from a virtually null level in sham condition. Solid boxes in the dorsal horn drawing indicate typical sites from which micrographs were taken for analysis. Bar diagrams represent intensity correlation-based analyses in confocal triple-labeled tissue photomicrographs, using the Pearson correlation coefficient as a measure of pixel-wise colocalization. SNL was followed by a significant increase in intensity correlation coefficients denoting colocalization of D1R, met-enkephalin and synaptophysin ${ }^{* *} p<0.01$, Fisher exact test relative to sham condition). A tentative interpretation of findings is summarized schematically. Although D1R expressed in presumed glutamatergic, met-enkephalin-containing boutons is virtually absent from presynaptic active sites in the basal condition, both D1R and met-enkephalin are upregulated to presynaptic specializations following nerve injury. Color codes for presynaptic density, met-enkephalin, and D1R are consistent with immunofluorescence channels. Descending dopaminergic volume transmission (DA) presumably arising from the A11 region is represented as a dopaminergic varicosity.
} 


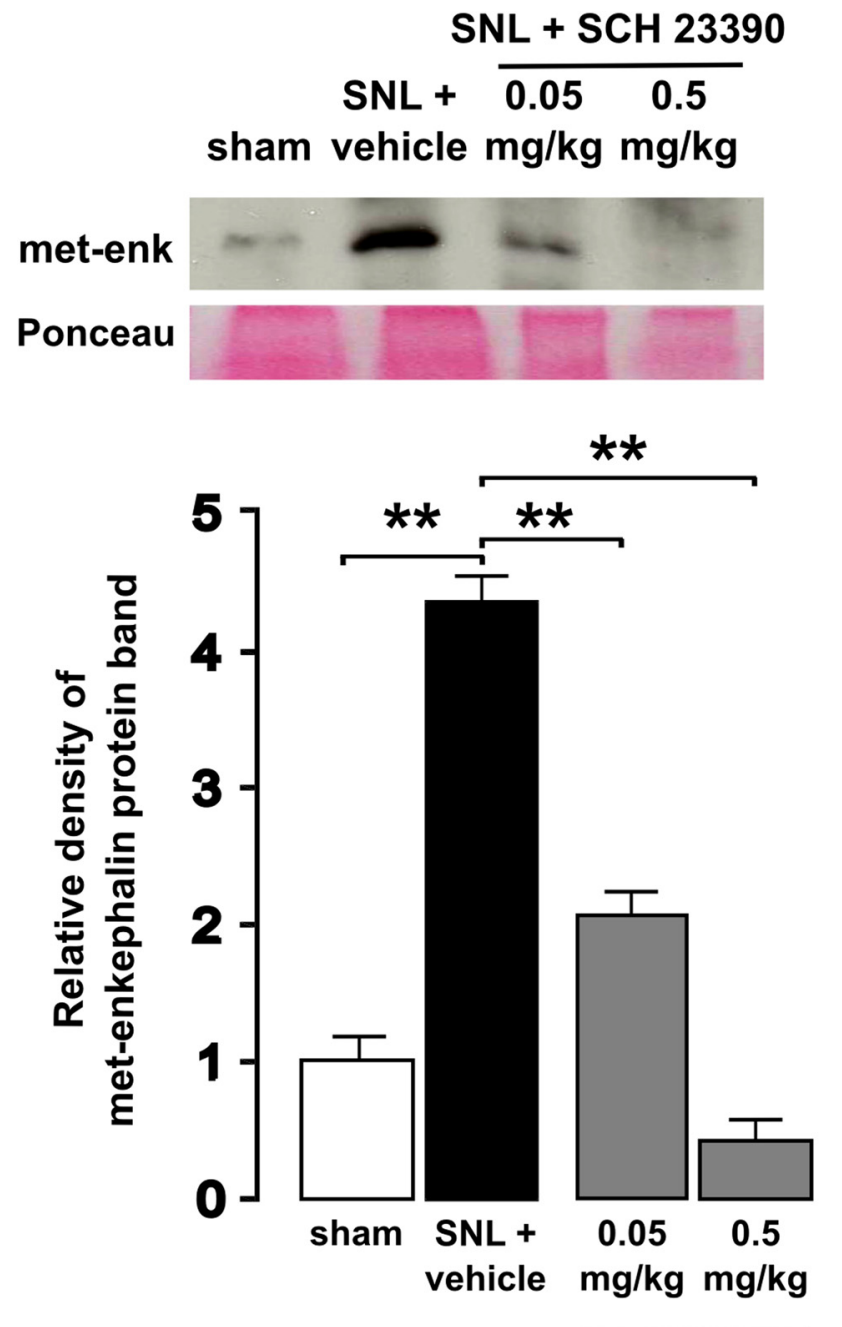

SNL + SCH 23390

Figure 5. D1LRs are responsible for upregulation of met-enkephalin after SNL. Western blot of dorsal horn homogenates shows increased immunoreactivity for met-enkephalin in nerveinjured rats compared with sham-operated ones, as well as the effect of postoperative treatment with D1LR antagonist SCH 23390 during the next $9 \mathrm{~d}$ following injury. Ponceau staining was used to confirm equal protein loading. Image-based quantitation of the immunoreactive bands normalized to band density in the sham condition reveal a more than fourfold increase after SNL. Met-enkephalin upregulation is significantly and dose-dependently attenuated by SCH 23390 treatment. Asterisks indicate statistical significance at $p<0.01$ using Student's $t$ test. Error bars indicate SEM.

blockade with SCH 23390. In confirmation of the above view, we found that DAMGO effectively activated the MOR regardless of D1LR blockade, indeed preventing LTP (Fig. 6).

Sustained D1LR activation following spinal nerve injury impairs the ability of MOR to repress synaptic plasticity We sought to determine whether the ability of the spinal MOR to repress afferent-induced synaptic plasticity was preserved during established central sensitization and sustained pain after peripheral nerve injury. To investigate for this, the occurrence of LTP after conditioning LFS was assessed in rats that had been subjected to SNL $9 \mathrm{~d}$ before. We found that LFS at either 0.2 or $3 \mathrm{~Hz}$ consistently induced LTP of C-fiber-evoked potentials (by $54.12 \pm 0.51 \%$ or $68.89 \pm 0.39 \%$, respectively; both $p<0.01, n=$ 6; Fig. 7A). Moreover, we found that LTP was effectively pre-
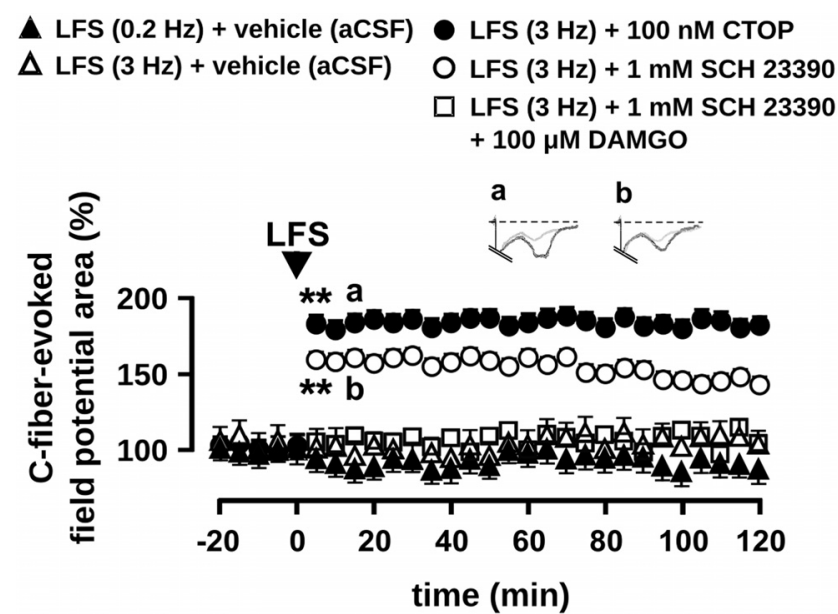

Figure 6. Conditioning LFS induces LTP during blockade of either D1LRs or MOR. Areas of C fiber-evoked field potentials in the spinal dorsal horn are plotted against time prior and after application of conditioning stimulation in the form of two $30 \mathrm{~s}$ trains of $3 \mathrm{~mA}, 1.5 \mathrm{~ms}$ duration pulses administered at low-frequency (either 0.2 or $3 \mathrm{~Hz}$ ), $30 \mathrm{~s}$ apart. The time axis is labeled relative to the time-point of conditioning stimulation. Conditioning stimulation at $3 \mathrm{~Hz}$ induced LTP of C-fiber-evoked potentials in the presence of either MOR- or D1LR antagonist drugs CTOP or SCH 23390, respectively, whereas no change in evoked potentials occurred after conditioning stimulation at either frequency during spinal superfusion with vehicle (aCSF). In rats receiving spinal superfusion with SCH 23390, acute DAMGO administration starting 2 min before LFS prevented the occurrence of LTP. Asterisks indicate statistically significant increase $(p<0.01)$ in evoked potentials compared with baseline recordings before conditioning stimulation, using the post hoc Bonferroni test following one-way ANOVA ( $n=6$ in each experimental condition). For clarity, only the first significantly increased potentials are labeled with asterisks. Individual field potentials from representative experiments using CTOP $(\boldsymbol{a})$ or SCH $23390(\boldsymbol{b})$ are shown above the plot. Error bars indicate SEM.

vented by spinal superfusion with the NMDA receptor antagonist D-AP5 $(100 \mu \mathrm{M})$.

If sustained activation of D1LRs following SNL was responsible for impairing the ability of MOR to prevent LTP, then keeping D1LRs blocked after injury should predictably preserve MOR function. This issue was addressed by attempting LTP induction $9 \mathrm{~d}$ after SNL in rats that had received daily intraperitoneal injections of D1LR antagonist SCH 23390 at either $0.05 \mathrm{mg} / \mathrm{kg}$ or 0.5 $\mathrm{mg} / \mathrm{kg}$. In addition, the effect of the same antagonist doses on phasic activation of D1LRs during LTP induction, ie, in the absence of prior daily administration, was evaluated in non-injured rats by administering the drug $20 \mathrm{~min}$ before LFS. In uninjured rats, we found that an acute injection of SCH 23390 at $0.05 \mathrm{mg} / \mathrm{kg}$ before LFS, ie, a dose effectively preventing met-enkephalin upregulation in dorsal horn neurons (compare Fig. 5), failed to block phasic activation of D1LRs, thereby permitting LTP to occur (Fig. $7 B$ ). In contrast, LTP was prevented by the antagonist only at the higher dose $(0.5 \mathrm{mg} / \mathrm{kg})$. These findings showed that a higher antagonist dose was required to block phasic D1LR activation during LTP induction than to prevent sustained activation leading to met-enkephalin upregulation following SNL. In nerveinjured rats chronically treated with SCH 23390, we found that the ability of the MOR to repress afferent-induced plasticity was fully preserved by using the drug at $0.05 \mathrm{mg} / \mathrm{kg}$, ie, at the dose effectively blocking met-enkephalin upregulation but not preventing phasic activation of D1LRs during LTP induction (Fig. 7B). A mild but statistically significant potentiation (26.79 \pm $0.50 \%, p<0.01, n=6$; Fig. 5) after LFS was found in nerveligated rats that had been treated with higher dose of SCH 23390 $(0.5 \mathrm{mg} / \mathrm{kg})$, presumably by effect of blockade of phasic D1LR activation during application of the conditioning LFS. 


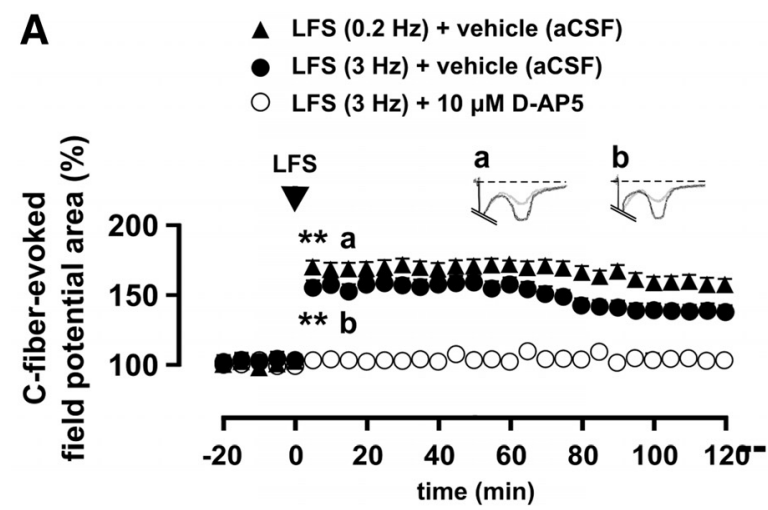

B

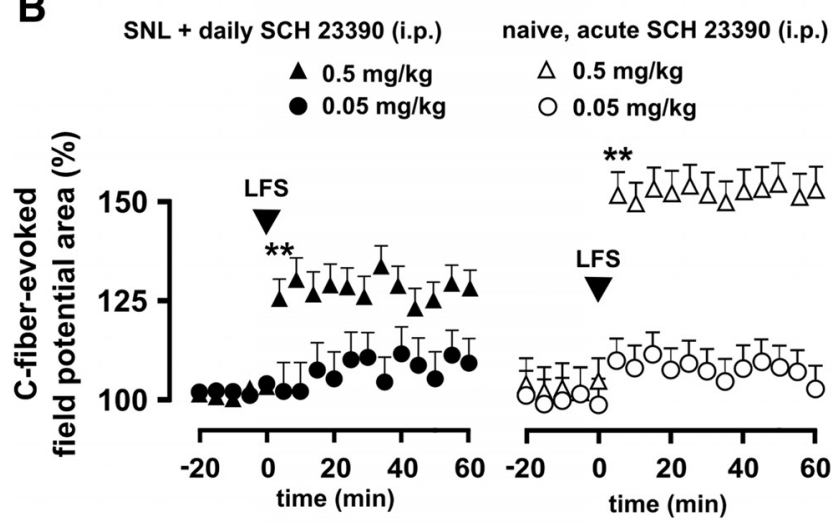

C

A SNL + daily vehicle (i.p.)

SNL + daily SCH 23390 (0.5 mg(kg, i.p.)

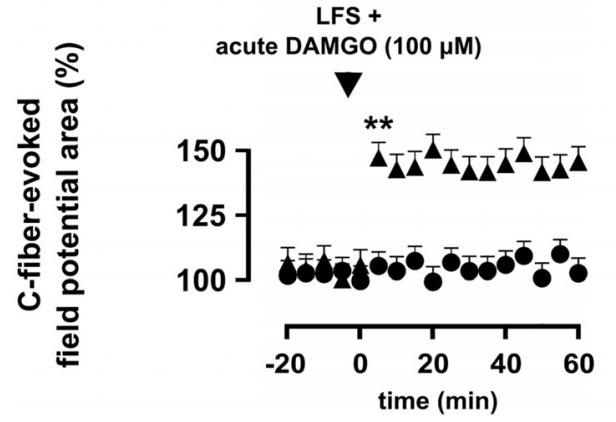

Figure 7. D1LRs are responsible for the loss of endogenous repression of synaptic plasticity after SNL. $A$, In rats subjected to SNL $9 \mathrm{~d}$ before, conditioning LFS induces NMDA receptordependent LTP of C-fiber-evoked potentials. The time course of changes induced by conditioning stimulation is shown and two examples of enhanced potentials from representative experiments are provided (gray traces correspond to control baseline recordings). B, Postoperative blockade of D1LR activity after SNL by daily intraperitoneal injections of SCH 23390 preserves the ability of endogenous repression of LTP. The phenomenon is best exemplified by nerve-ligated rats (left graph) that had received $0.05 \mathrm{mg} / \mathrm{kg} \mathrm{SCH} 23390$ chronically, in which phasic activation of D1LRs was however unaffected. The graph on the right represents data from experiments in naive rats, demonstrating that phasic activation of D1LRs to repress LFS-induced LTP is blocked by SCH 23390 only at $0.5 \mathrm{mg} / \mathrm{kg}$ but not at $0.05 \mathrm{mg} / \mathrm{kg}$ dose. C, Acute activation of MOR by addition of DAMGO to the spinal superfusate 2 min before LFS prevents LTP formation only in rats in which sustained D1R activation after SNL has been prevented by daily postoperative injections of $\mathrm{SCH} 23390$. In all four graphs, asterisks denote statistically significant increase of mean potential areas $(p<0.01)$ compared with potentials from the baseline control period before LFS, using the post hoc Bonferroni test following one-way ANOVA. Only the first significantly increased potentials have been labeled with asterisks. Error bars in all graphs indicate SEM.
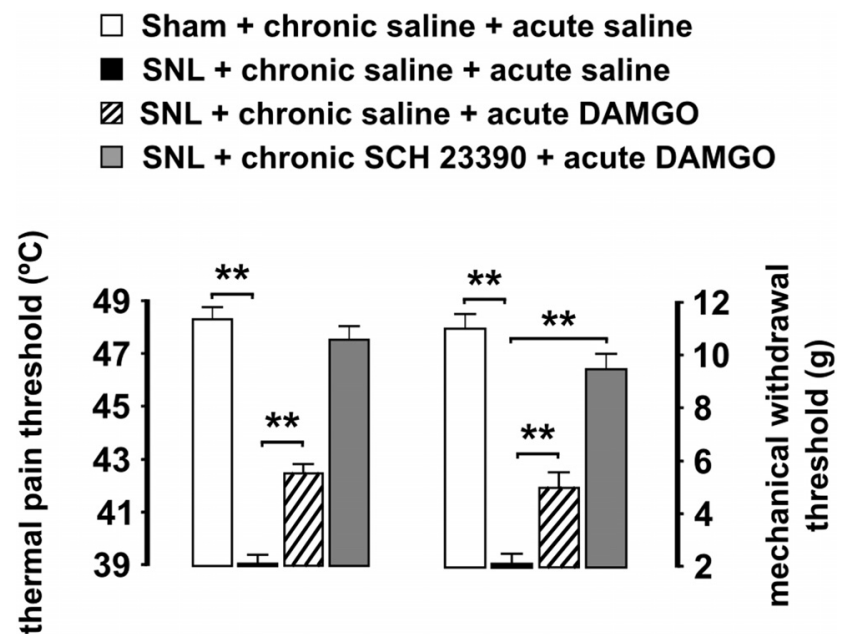

Figure 8. Thermal and mechanical MOR antinociception after SNL is preserved by D1LR blockade. Heat pain thresholds assessed in the hot plate test and the 50\% paw withdrawal threshold to a static mechanical stimulus with von Frey monofilaments are shown $9 \mathrm{~d}$ after SNL. Thermal and mechanical thresholds, both of which are significantly lowered after SNL on the injury side $9 \mathrm{~d}$ after surgery, are significantly but only partially reversed by acute administration of DAMGO (i.p.) before behavioral evaluation. However, DAMGO dramatically raises both thermal and mechanical thresholds to near-normal levels in rats that have been treated with $\mathrm{SCH}$ 23390 but not with vehicle (isotonic saline) on a daily basis. Asterisks indicate statistical significance $(p<0.01)$ at comparisons using the Student's $t$ test. Error bars indicate SEM.

In addition, we sought to ascertain whether abolishing sustained synaptic activation of D1LRs after nerve injury would also preserve MOR responsiveness to exogenous activation by an agonist drug. To this end, in nerve-injured rats chronically treated with SCH 23390 we assessed the ability of acutely administered DAMGO (100 $\mu \mathrm{M}$, via spinal superfusion) starting just before conditioning stimulation to prevent the induction of LTP. We found that DAMGO effectively prevented LTP in SCH 23390treated rats $(0.5 \mathrm{mg} / \mathrm{kg}$, i.p.) but not in vehicle-treated rats (38.05 $\pm 0.46 \%$ increase, relative to before LFS; $p<0.01, n=6$; Fig. 7).

Enhanced synaptic activation of D1LRs following SNL impairs MOR-mediated behavioral thermal and mechanical analgesia

To better understand how upregulation of D1LRs following SNL affects MOR antinociception, we evaluated the ability of an acute administration of DAMGO (1.5 mg/kg, i.p.) to relieve behavioral thermal and mechanical nociception $9 \mathrm{~d}$ after surgery in conscious, nerve-injured rats. Injured rats treated both chronically and acutely with vehicle (isotonic saline) exhibited marked mechanical and thermal allodynia at the side of injury, as shown by dramatic decrease in paw withdrawal thresholds both to plantar stimulation with von Frey monofilaments and thermal simulation in the hot plate test (mechanical threshold of $2.13 \pm 0.30 \mathrm{~g}$ vs $10.83 \pm 0.40 \mathrm{~g}$ in sham-operated rats, and thermal threshold of $39.09 \pm 0.27^{\circ} \mathrm{C}$ vs $48.13 \pm 0.31^{\circ} \mathrm{C}$ in the sham condition; $p<0.01$ in both contrasts, Student's $t$ test, $n=6$ ). In these rats, DAMGO produced a statistically significant $(4.91 \pm 0.42 \mathrm{~g}$ mechanical threshold vs $2.13 \pm 0.30 \mathrm{~g}$ before DAMGO, and $42.48 \pm 0.23^{\circ} \mathrm{C}$ thermal threshold vs $39.09 \pm 0.27^{\circ} \mathrm{C}$ before DAMGO; $p<0.01$ in both contrasts, Student's $t$ test, $n=6$ ) but only partial reversal of thermal and mechanical thresholds (Fig. 8). In contrast, in nerveinjured rats that were chronically treated with $\mathrm{SCH} 23390$, an acute injection of DAMGO effectively increased mechanical thresholds to a level close to that measured in sham-operated 


\section{$\triangle$ D1R priming O D1R priming + acute CTOP $(10 \mu \mathrm{M})$}

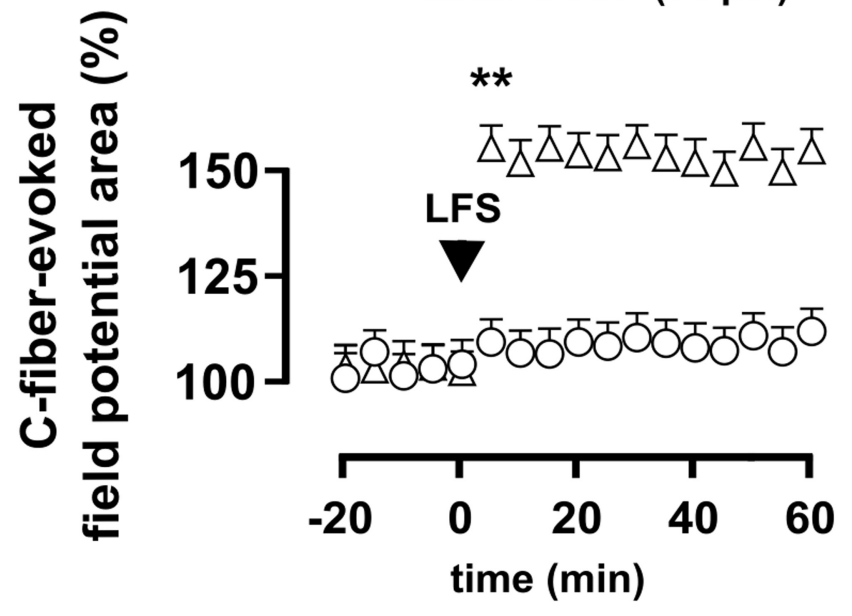

Figure 9. Rapid MOR dysfunction following sustained D1LR activation. Priming D1LRs with SKF 38393 for 30 min before conditioning stimulation suffices to impair endogenous, MORmediated repression of LTP. Blocking MOR activation (CTOP, intensively washed out for 5 min before LFS) during D1LR priming preserves the ability of MOR to prevent the occurrence of LTP. Asterisks indicate statistical significance $(p<0.01)$ when field potential magnitudes prior and after conditioning stimulation are compared using the post hoc Bonferroni test following oneway ANOVA ( $n=6$ in each experimental condition; error bars $=$ SEM). For clarity, only the earliest statistically significant effects are labeled with asterisks.

animals $(9.49 \pm 0.43 \mathrm{~g}, p<0.01$, Student's $t$ test vs before DAMGO), and thermal thresholds were fully restored to those measured in sham-operated animals $\left(47.52 \pm 0.35^{\circ} \mathrm{C} ; p<0.01\right.$, Student's $t$ test vs before DAMGO, and $p=0.07$ vs shamoperated controls). The increases in thermal and mechanical thresholds after DAMGO administration were significantly higher in SCH 23390-treated rats than in those receiving only vehicle as chronic treatment $(p<0.01$, Student's $t$ test between treatment conditions in both sensory modalities).

\section{Rapid impairment of MOR function following D1LR activation}

To gain insight into the timing of functional MOR impairment after the onset of sustained D1LR activation, we primed D1LRs in the spinal dorsal horn by superfusion with SKF $38393(100 \mu \mathrm{M})$ in naive rats, before applying conditioning LFS. The results showed that priming D1LRs for $30 \mathrm{~min}$ was sufficient to impair the ability of the MOR to prevent LTP after conditioning, low-frequency input $(53.02 \pm 0.51 \%, p<0.01$, $n=6$; Fig. 9). In separate experiments we found that simultaneous blockade of MOR with CTOP $(10 \mu \mathrm{M}$; intensively washed out for 5 min before LFS) during D1LR priming successfully preserved the ability of MOR to prevent LTP, suggesting that the functional impairment of MOR secondary to D1LR priming was due to sustained MOR activation.

\section{Discussion}

\section{D1LRs depress spinal excitability via MOR}

The current study shows that D1LRs depress evoked excitation of dorsal horn neurons, adding to previous evidence supporting general antinociceptive actions of dopamine at the dorsal horn (Tamae et al., 2005; Taniguchi et al., 2011). D1LR-mediated modulation became operative in the nerve-injured condition, which was consistent with the failure of D1R to modulate me- chanical nociceptive thresholds or evoked responses to acute C-fiber input in naive animals (Tamae et al., 2005; Yang et al., 2005), as well as with the reported attenuation of nociceptive behaviors by D1LR agonists only in the second phase of the formalin test in rats and mice (Zarrindast et al., 1999; Munro, 2007). Considering that D1LRs can attenuate neuronal excitation by enhancing opioid- or GABA-mediated inhibition (Schoffelmeer et al., 2000; Mango et al., 2014), we assessed the ability of D1LRs to depress evoked potentials in the presence of drugs reducing endogenous activation of $\mu$-opioid or GABA receptors. Blockade of the $\mu$-opioid, but not GABA receptor, abolished the depression of evoked potentials induced by D1LRs in nerve-ligated rats, suggesting an intervening role for endogenous activation of the MOR.

Dopamine D1 and D2 receptor families both have been implicated in heterosynaptic regulation of neurotransmitter release (Tritsch and Sabatini, 2012), and there is evidence supporting heterosynaptic facilitation via D1LRs (Cameron and Williams, 1993; Trudeau et al., 1996; Chen and Regehr, 1997). We hypothesized that dopaminergic input to the dorsal horn may interact with the MOR by intermediation of enkephalinergic terminals, because enkephalins are major opioid ligands in the spinal dorsal horn (Marvizón et al., 2009; Huang et al., 2010), with high affinity for MOR (Delfs et al., 1994; Raynor et al., 1994; Fields, 2004) and enkephalin and D1LRs both are present in the dorsal horn (Todd and Spike, 1992; Zhu et al., 2007). We found that D1R and metenkephalin colocalized with presynaptic marker synaptophysin, supporting D1R expression in presynaptic enkephalinergic boutons. The absence of D1R and met-enkephalin in GABAergic neurons was consistent with the observed lack of physiological interaction of D1LRs with GABA receptors. Enkephalin is present in intrinsic excitatory and GABAergic neurons in the dorsal horn (Todd and Spike, 1992, Todd et al., 2003; Marvizón et al., 2007, 2009; Huang et al., 2010), rather than in afferent C-fibers (Marvizón et al., 2009). Our present confocal immunofluorescence data reveal the presence of D1R and met-enkephalin in neurons immunopositive for vesicular glutamate transporter VGLUT2, a marker of glutamatergic neurons, but not in those containing vGAT, a marker of GABAergic terminals. Probable postsynaptic targets of enkephalinergic terminals may include primary afferent terminals (Mansour et al., 1994, 1995; Ji et al., 1995; Li et al., 1998) or excitatory interneurons in the dorsal horn (Arvidsson et al., 1995; Kemp et al., 1996).

Because SCH 23390 targets both D1 and D5 receptor subtypes, the observed depressing action of the drug did not permit us to discriminate their relative contribution. In situ hybridization signal for D5R is indeed reportedly present in the dorsal horn (Zhu et al., 2007), and recent evidence suggests that D5R might contribute to sustained pain (Kim et al., 2015). Nonetheless, although we cannot rule out a contribution of D5 to D1LR-MOR interaction, we present evidence that the polyclonal antibody to D1R used here selectively recognized the D1 subtype, providing strong support for the involvement of D1R in the plasticity phenomena revealed by immunocytochemical and Western blot data.

Upregulation of D1LRs increases met-enkephalin availability We show here that SNL triggers changes in the expression and subcellular organization of D1R and met-enkephalin. We found an increase in D1R-like immunoreactivity in synaptic fraction (P3) in dorsal horn homogenates from nerve-injured rats, which confocal immunofluorescence located to presynaptic active zones in met-enkephalin-containing neurons (Fig. 4). A probable 
underlying mechanism may be a rise in spinal dopamine release following SNL analogous to that observed after intraplantar carrageenan injections (Gao et al., 2001), because D1R responds to prolonged exposure to dopamine by rapid recycling with high rates of repositioning to the cell membrane (Ariano et al., 1997; Bartlett et al., 2005).

We found an over fourfold increase in immunoreactivity for met-enkephalin after SNL, in keeping with observations in different models of experimental pain (Sommer and Myers, 1995; Calzà et al., 1998; Hossaini et al., 2014). Increased release of metenkephalin and sustained MOR activation (Buesa et al., 2008) are conceivably compensatory changes for increased nociceptive input. Attenuation of met-enkephalin upregulation as shown here by postoperative blockade of D1LRs demonstrates that dopaminergic input to the dorsal horn is instrumental in sustaining increased MOR activity.

\section{D1LRs regulate the threshold for synaptic plasticity}

Conditioning LFS consistently induced synaptic LTP of C-fiberevoked dorsal horn potentials in rats subjected to MOR blockade, but not in untreated rats, unmasking a constitutive role of MOR in repressing afferent-induced central plasticity. LTP at dorsal horn synapses is considered as a major substrate of hyperalgesia and central sensitization in the pain signaling pathway to the brain (Ji et al., 2003; Sandkühler, 2007; Sandkühler and GruberSchoffnegger, 2012). These findings suggest that the MOR may be recruited endogenously by repetitive afferent input rather than by single, acute stimuli, in line with previous observations that the MOR specifically represses the wind-up response to repeated noxious input (Guan et al., 2006) and interferes with the induction mechanisms of LTP following afferent high-frequency stimulation in the in vitro slice preparation (Terman et al., 2001). The permissive effect of MOR blockade on LTP induction could be reproduced here by blocking D1LRs, supporting that dopaminergic input to the dorsal horn is integral to constitutive repression of spinal sensitization. Direct activation of MOR by DAMGO prevented LTP occurrence regardless of D1LR blockade, indicating that D1LRs may not act by directly regulating MOR responsiveness.

Dopaminergic A11-spinal neurons have been suggested to mediate the so-termed diffuse noxious inhibitory controls via recruitment of the D2 receptor subtype (Lapirot et al., 2011). Our data extend those findings by showing that D1LRs are recruited largely in response to either repetitive conditioning stimulation at the C-fiber strength or afferent barrage associated with experimental nerve injury.

\section{Sustained D1LR activation impairs MOR function}

Conditioning LFS consistently induced LTP of C-fiber-evoked potentials in nerve-injured rats, demonstrating that endogenous repression of synaptic plasticity is impaired during sustained pain. LTP was NMDA receptor-dependent, as shown by the blocking effect of D-AP5, in keeping with most prior reports addressing this form of synaptic plasticity (Randić et al., 1993; Liu and Sandkühler, 1995; Svendsen et al., 1998; Pedersen and Gjerstad, 2008; Zhou et al., 2008; Qu et al., 2009). Studies suggest that tolerance to endogenous opioids secondary to augmented opioidergic neurotransmission during sustained pain may decrease sensitivity to opiate analgesics (Xu et al., 2004). SNL may provide unique conditions by increasing met-enkephalin turnover as found here. We show that D1LR upregulation leads to MOR dysfunction via sustained activation of the receptor. Thus, endogenous repression of LTP (Fig. 6) was fully preserved in nerve- injured in rats that had been treated postoperatively with $\mathrm{SCH}$ 23390 at a sufficient dose to prevent met-enkephalin upregulation. Furthermore, chronic D1LR blockade after SNL preserved MOR responsiveness to opiate drugs, as supported by two lines of evidence. First, MOR could be successfully activated in nerveinjured rats that were chronically treated with SCH 23390, as demonstrated by the effectiveness of MOR agonist DAMGO to repress LTP induction. Second, the ability of DAMGO to raise thermal and mechanical pain thresholds, which was significantly impaired after SNL, could be preserved or restored to nearnormal levels in SCH 23390-treated rats (Fig. 8).

By pharmacologically stimulating D1LRs in naive rats, we reproduced MOR dysfunction brought about by sustained endogenous D1LR activation. Priming D1LRs for $30 \mathrm{~min}$ by spinal superfusion with SKF 38393 sufficed to disrupt the ability of MOR to repress LTP (Fig. 9), revealing that the impairment of this aspect of MOR function is actually a rapidly evolving phenomenon that requires D1LR activation. Moreover, we found that endogenous repression of LTP was preserved during D1LR priming whenever sustained activation of MOR was simultaneously blocked with CTOP, further supporting that disruption of MOR function was due to sustained receptor activation. This time frame of D1LR priming is consistent with the reported rise of extracellular dopamine in the dorsal horn in response to noxious input (Gao et al., 2001). Furthermore, there are indications that continued D1LR activation may lead to MOR dysfunction in a progressive manner, because sustained D1LR stimulation by a higher concentration of SKF $38393(250 \mu \mathrm{M})$ may lead to lateonset disinhibition of evoked potentials in the absence of conditioning stimulation (Yang et al., 2005).

Central sensitization is characterized by increased gain of the nociceptive system to afferent signals (Woolf and Salter, 2000; Latremoliere and Woolf, 2009). We provide novel evidence that MOR-mediated modulation of central excitability to noxious input and MOR-mediated repression of synaptic plasticity both are regulated by dopaminergic, D1R-mediated neurotransmission. Whereas D1R-regulated recruitment of MOR is both an adaptive mechanism compensating for increased nociceptive input after peripheral nerve injury and instrumental in preventing central sensitization, sustained activation of this mechanism impairs MOR compliance and increases the probability for subsequent milder, otherwise subthreshold afferent inputs to trigger changes in sensory gain.

\section{References}

Aira Z, Buesa I, García del Caño G, Salgueiro M, Mendiable N, Mingo J, Aguilera L, Bilbao J, Azkue JJ (2012) Selective impairment of spinal muopioid receptor mechanism by plasticity of serotonergic facilitation mediated by 5-HT2A and 5-HT2B receptors. Pain 153:1418-1425. CrossRef Medline

Aira Z, Buesa I, García del Caño G, Bilbao J, Doñate F, Zimmermann M, Azkue JJ (2013) Transient, 5-HT2B receptor-mediated facilitation in neuropathic pain: up-regulation of PKC $\gamma$ and engagement of the NMDA receptor in dorsal horn neurons. Pain 154:1865-1877. CrossRef Medline Aira Z, Barrenetxea T, Buesa I, Gómez-Esteban JC, Azkue JJ (2014) Synaptic upregulation and superadditive interaction of dopamine D2- and $\mu$-opioid receptors after peripheral nerve injury. Pain 155:2526-2533. CrossRef Medline

Aira Z, Barrenetxea T, Buesa I, Azkue JJ (2015) Plasticity of $\alpha 2$-adrenergic spinal antinociception following nerve injury: selective, bidirectional interaction with the delta opioid receptor. Brain Res 1594:190-203. CrossRef Medline

Aldridge GM, Podrebarac DM, Greenough WT, Weiler IJ (2008) The use of total protein stains as loading controls: an alternative to high-abundance single-protein controls in semi-quantitative immunoblotting. J Neurosci Methods 172:250-254. CrossRef Medline 
Almási R, Pethö G, Bölcskei K, Szolcsányi J (2003) Effect of resiniferatoxin on the noxious heat threshold temperature in the rat: a novel heat allodynia model sensitive to analgesics. Br J Pharmacol 139:49-58. CrossRef Medline

Ariano MA, Sortwell CE, Ray M, Altemus KL, Sibley DR, Levine MS (1997) Agonist-induced morphologic decrease in cellular $\mathrm{D}_{1 \mathrm{~A}}$ dopamine receptor staining. Synapse 27:313-321. CrossRef Medline

Arvidsson U, Riedl M, Chakrabarti S, Lee JH, Nakano AH, Dado RJ, Loh HH, Law PY, Wessendorf MW, Elde R (1995) Distribution and targeting of a $\mu$-opioid receptor (MOR1) in brain and spinal cord. J Neurosci 15: 3328-3341. Medline

Aubert I, Guigoni C, Håkansson K, Li Q, Dovero S, Barthe N, Bioulac BH, Gross CE, Fisone G, Bloch B, Bezard E (2005) Increased D1 dopamine receptor signaling in levodopa-induced dyskinesia. Ann Neurol 57:17-26. CrossRef Medline

Azkue JJ, Liu XG, Zimmermann M, Sandkühler J (2003) Induction of longterm potentiation of $\mathrm{C}$ fibre-evoked spinal field potentials requires recruitment of group I, but not group II/III metabotropic glutamate receptors. Pain 106:373-379. CrossRef Medline

Barraud Q, Obeid I, Aubert I, Barrière G, Contamin H, McGuire S, Ravenscroft P, Porras G, Tison F, Bezard E, Ghorayeb I (2010) Neuroanatomical study of the A11 diencephalospinal pathway in the non-human primate. PLoS One 5:e13306. CrossRef Medline

Bartlett SE, Enquist J, Hopf FW, Lee JH, Gladher F, Kharazia V, Waldhoer M, Mailliard WS, Armstrong R, Bonci A, Whistler JL (2005) Dopamine responsiveness is regulated by targeted sorting of D2 receptors. Proc Natl Acad Sci U S A 102:11521-11526. CrossRef Medline

Beaulieu JM, Gainetdinov RR (2011) The physiology, signaling, and pharmacology of dopamine receptors. Pharmacol Rev 63:182-217. CrossRef Medline

Beck H, Schröck H, Sandkühler J (1995) Controlled superfusion of the rat spinal cord for studying non-synaptic transmission: an autoradiographic analysis. J Neurosci Methods 58:193-202. CrossRef Medline

Becker A, Grecksch G, Kraus J, Peters B, Schroeder H, Schulz S, Höllt V (2001) Loss of locomotor sensitisation in response to morphine in D1 receptor deficient mice. Naunyn Schmiedebergs Arch Pharmacol 363: 562-568. CrossRef Medline

Bigal ME, Lipton RB (2009) Overuse of acute migraine medications and migraine chronification. Curr Pain Headache Rep 13:301-307. CrossRef Medline

Brewer KL, Baran CA, Whitfield BR, Jensen AM, Clemens S (2014) Dopamine D3 receptor dysfunction prevents anti-nociceptive effects of morphine in the spinal cord. Front Neural Circuits 8:62. CrossRef Medline

Buesa I, Ortiz V, Aguilera L, Torre F, Zimmermann M, Azkue JJ (2006) Disinhibition of spinal responses to primary afferent input by antagonism at GABA receptors in urethane-anaesthetised rats is dependent on NMDA and metabotropic glutamate receptors. Neuropharmacology 50:585-594. CrossRef Medline

Buesa I, Urrutia A, Aira Z, Salgueiro M, Bilbao J, Mozas M, Aguilera L, Zimmermann M, Azkue JJ (2008) Depression of C fibre-evoked spinal field potentials by the spinal delta opioid receptor is enhanced in the spinal nerve ligation model of neuropathic pain: involvement of the musubtype. Neuropharmacology 55:1376-1382. CrossRef Medline

Burgess SE, Gardell LR, Ossipov MH, Malan TP Jr, Vanderah TW, Lai J, Porreca F (2002) Time-dependent descending facilitation from the rostral ventromedial medulla maintains, but does not initiate, neuropathic pain. J Neurosci 22:5129-5136. Medline

Calzà L, Pozza M, Zanni M, Manzini CU, Manzini E, Hökfelt T (1998) Peptide plasticity in primary sensory neurons and spinal cord during adjuvant-induced arthritis in the rat: an immunocytochemical and in situ hybridization study. Neuroscience 82:575-589. CrossRef Medline

Cameron DL, Williams JT (1993) Dopamine D1 receptors facilitate transmitter release. Nature 366:344-347. CrossRef Medline

Cao J, Yang X, Liu YN, Suo ZW, Shi L, Zheng CR, Yang HB, Li S, Hu XD (2011) GABAergic disinhibition induced pain hypersensitivity by upregulating NMDA receptor functions in spinal dorsal horn. Neuropharmacology 60:921-929. CrossRef Medline

Chaplan SR, Bach FW, Pogrel JW, Chung JM, Yaksh TL (1994) Quantitative assessment of tactile allodynia in the rat paw. J Neurosci Methods 53: 55-63. CrossRef Medline

Charbit AR, Akerman S, Holland PR, Goadsby PJ (2009) Neurons of the dopaminergic/calcitonin gene-related peptide A11 cell group modulate neuronal firing in the trigeminocervical complex: an electrophysiological and immunohistochemical study. J Neurosci 29:12532-12541. CrossRef Medline

Chen C, Regehr WG (1997) The mechanism of cAMP-mediated enhancement at a cerebellar synapse. J Neurosci 17:8687-8694. Medline

Chen TC, Cheng YY, Sun WZ, Shyu BC (2008) Differential regulation of morphine antinociceptive effects by endogenous enkephalinergic system in the forebrain of mice. Mol Pain 4:41. CrossRef Medline

Christie MJ (2008) Cellular neuroadaptations to chronic opioids: tolerance, withdrawal and addiction. Br J Pharmacol 154:384-396. CrossRef Medline

Chu LF, Angst MS, Clark D (2008) Opioid-induced hyperalgesia in humans: molecular mechanisms and clinical considerations. Clin J Pain 24:479-496. CrossRef Medline

Delfs JM, Kong H, Mestek A, Chen Y, Yu L, Reisine T, Chesselet MF (1994) Expression of mu opioid receptor mRNA in rat brain: an in situ hybridization study at the single cell level. J Comp Neurol 345:46-68. CrossRef Medline

Dubois A, Savasta M, Curet O, Scatton B (1986) Autoradiographic distribution of the D1 agonist [3H]SKF 38393, in the rat brain and spinal cord. Comparison with the distribution of D2 dopamine receptors. Neuroscience 19:125-137. CrossRef Medline

Fields H (2004) State-dependent opioid control of pain. Nat Rev Neurosci 5:565-575. CrossRef Medline

Fleetwood-Walker SM, Hope PJ, Mitchell R (1988) Antinociceptive actions of descending dopaminergic tracts on cat and rat dorsal horn somatosensory neurones. J Physiol 399:335-348. CrossRef Medline

Gao X, Zhang YQ, Zhang LM, Wu GC (2001) Effects of intraplantar injection of carrageenan on central dopamine release. Brain Res Bull 54: 391-394. CrossRef Medline

Guan Y, Borzan J, Meyer RA, Raja SN (2006) Windup in dorsal horn neurons is modulated by endogenous spinal $\mu$-opioid mechanisms. J Neurosci 26:4298-4307. CrossRef Medline

Hay JL, White JM, Bochner F, Somogyi AA, Semple TJ, Rounsefell B (2009) Hyperalgesia in opioid-managed chronic pain and opioid-dependent patients. J Pain 10:316-322. CrossRef Medline

Hökfelt T, Phillipson O, Goldstein M (1979) Evidence for a dopaminergic pathway in the rat descending from the A11 cell group to the spinal cord. Acta Physiol Scand 107:393-395. CrossRef Medline

Hossaini M, Duraku LS, Kohli SK, Jongen JL, Holstege JC (2014) Spinal distribution of c-Fos activated neurons expressing enkephalin in acute and chronic pain models. Brain Res 1543:83-92. CrossRef Medline

Huang J, Chen J, Wang W, Wang W, Koshimizu Y, Wei YY, Kaneko T, Li YQ, Wu SX (2010) Neurochemical properties of enkephalinergic neurons in lumbar spinal dorsal horn revealed by preproenkephalin-green fluorescent protein transgenic mice. J Neurochem 113:1555-1564. CrossRef Medline

Ji RR, Zhang Q, Law PY, Low HH, Elde R, Hökfelt T (1995) Expression of $\mu$-, $\delta$-, and $\kappa$-opioid receptor-like immunoreactivities in rat dorsal root ganglia after carrageenan-induced inflammation. J Neurosci 15: 8156-8166. Medline

Ji RR, Kohno T, Moore KA, Woolf CJ (2003) Central sensitization and LTP: do pain and memory share similar mechanisms? Trends Neurosci 26: 696-705. CrossRef Medline

Joseph EK, Levine JD (2010) Multiple PKC $\varepsilon$-dependent mechanisms mediating mechanical hyperalgesia. Pain 150:17-21. CrossRef Medline

Kemp T, Spike RC, Watt C, Todd AJ (1996) The mu-opioid receptor (MOR1) is mainly restricted to neurons that do not contain GABA or glycine in the superficial dorsal horn of the rat spinal cord. Neuroscience 75:1231-1238. CrossRef Medline

Kim JY, Tillu DV, Quinn TL, Mejia GL, Shy A, Asiedu MN, Murad E, Schumann AP, Totsch SK, Sorge RE, Mantyh PW, Dussor G, Price TJ (2015) Spinal dopaminergic projections control the transition to pathological pain plasticity via a D1/D5-mediated mechanism. J Neurosci 35: 6307-6317. CrossRef Medline

Kim SH, Chung JM (1992) An experimental model for peripheral neuropathy produced by segmental spinal nerve ligation in the rat. Pain 50: 355-363. CrossRef Medline

Kovelowski CJ, Ossipov MH, Sun H, Lai J, Malan TP, Porreca F (2000) Supraspinal cholecystokinin may drive tonic descending facilitation mechanisms to maintain neuropathic pain in the rat. Pain 87:265-273. CrossRef Medline 
Lapirot O, Melin C, Modolo A, Nicolas C, Messaoudi Y, Monconduit L, Artola A, Luccarini P, Dallel R (2011) Tonic and phasic descending dopaminergic controls of nociceptive transmission in the medullary dorsal horn. Pain 152:1821-1831. CrossRef Medline

Latremoliere A, Woolf CJ (2009) Central sensitization: a generator of pain hypersensitivity by central neural plasticity. J Pain 10:895-926. CrossRef Medline

Levant B, McCarson KE (2001) D(3) dopamine receptors in rat spinal cord: implications for sensory and motor function. Neurosci Lett 303:9-12. CrossRef Medline

Li JL, Ding YQ, Li YQ, Li JS, Nomura S, Kaneko T, Mizuno N (1998) Immunocytochemical localization of mu-opioid receptor in primary afferent neurons containing substance $P$ or calcitonin gene-related peptide: $a$ light and electron microscope study in the rat. Brain Res 794:347-352. CrossRef Medline

Li Q, Lau A, Morris TJ, Guo L, Fordyce CB, Stanley EF (2004) A syntaxin 1, $\mathrm{G} \alpha_{\mathrm{o}}$, and N-type calcium channel complex at a presynaptic nerve terminal: analysis by quantitative immunocolocalization. J Neurosci 24: 4070-4081. CrossRef Medline

Liu XG, Sandkühler J (1995) Long-term potentiation of C-fiber-evoked potentials in the rat spinal dorsal horn is prevented by spinal $N$-methyl-Daspartic acid receptor blockage. Neurosci Lett 191:43-46. CrossRef Medline

Mango D, Bonito-Oliva A, Ledonne A, Nisticò R, Castelli V, Giorgi M, Sancesario G, Fisone G, Berretta N, Mercuri NB (2014) Phosphodiesterase $10 \mathrm{~A}$ controls D1-mediated facilitation of GABA release from striatonigral projections under normal and dopamine-depleted conditions. Neuropharmacology 76:127-136. CrossRef Medline

Mansour A, Fox CA, Burke S, Meng F, Thompson RC, Akil H, Watson SJ (1994) Mu, delta, and kappa opioid receptor mRNA expression in the rat CNS: an in situ hybridization study. J Comp Neurol 350:412-438. CrossRef Medline

Mansour A, Fox CA, Burke S, Akil H, Watson SJ (1995) Immunohistochemical localization of the cloned mu opioid receptor in the rat CNS. J Chem Neuroanat 8:283-305. CrossRef Medline

Mao J (1999) NMDA and opioid receptors: their interactions in antinociception, tolerance and neuroplasticity. Brain Res Brain Res Rev 30:289-304. CrossRef Medline

Mao J, Mayer DJ (2001) Spinal cord neuroplasticity following repeated opioid exposure and its relation to pathological pain. Ann N Y Acad Sci 933:175-184. CrossRef Medline

Marvizón JC, Pérez OA, Song B, Chen W, Bunnett NW, Grady EF, Todd AJ (2007) Calcitonin receptor-like receptor and receptor activity modifying protein 1 in the rat dorsal horn: localization in glutamatergic presynaptic terminals containing opioids and adrenergic $\alpha 2 \mathrm{C}$ receptors. Neuroscience 148:250-265. CrossRef Medline

Marvizón JC, Chen W, Murphy N (2009) Enkephalins, dynorphins, and beta-endorphin in the rat dorsal horn: an immunofluorescence colocalization study. J Comp Neurol 517:51-68. CrossRef Medline

Munro G (2007) Dopamine D(1) and D(2) receptor agonism enhances antinociception mediated by the serotonin and noradrenaline reuptake inhibitor duloxetine in the rat formalin test. Eur J Pharmacol 575:66-74. CrossRef Medline

Neve KA, Seamans JK, Trantham-Davidson H (2004) Dopamine receptor signaling. J Recept Signal Transduct Res 24:165-205. CrossRef Medline

Ossipov MH, Lai J, Malan TP Jr, Porreca F (2000) Spinal and supraspinal mechanisms of neuropathic pain. Ann N Y Acad Sci 909:12-24. CrossRef Medline

Pedersen LM, Gjerstad J (2008) Spinal cord long-term potentiation is attenuated by the NMDA-2B receptor antagonist Ro 25-6981. Acta Physiol (Oxf) 192:421-427. CrossRef

Qu S, Ondo WG, Zhang X, Xie WJ, Pan TH, Le WD (2006) Projections of diencephalic dopamine neurons into the spinal cord in mice. Exp Brain Res 168:152-156. CrossRef Medline

Qu XX, Cai J, Li MJ, Chi YN, Liao FF, Liu FY, Wan Y, Han JS, Xing GG (2009) Role of the spinal cord NR2B-containing NMDA receptors in the development of neuropathic pain. Exp Neurol 215:298-307. CrossRef Medline

Randić M, Jiang MC, Cerne R (1993) Long-term potentiation and longterm depression of primary afferent neurotransmission in the rat spinal cord. J Neurosci 13:5228-5241. Medline

Raynor K, Kong H, Chen Y, Yasuda K, Yu L, Bell GI, Reisine T (1994) Phar- macological characterization of the cloned kappa-, delta-, and mu-opioid receptors. Mol Pharmacol 45:330-334. Medline

Romero-Calvo I, Ocón B, Martínez-Moya P, Suárez MD, Zarzuelo A, Martínez-Augustin O, de Medina FS (2010) Reversible Ponceau staining as a loading control alternative to actin in Western blots. Anal Biochem 401:318-320. CrossRef Medline

Sandkühler J (2007) Understanding LTP in pain pathways. Mol Pain 3:9. CrossRef Medline

Sandkühler J, Gruber-Schoffnegger D (2012) Hyperalgesia by synaptic long-term potentiation (LTP): an update. Curr Opin Pharmacol 12: 18-27. CrossRef Medline

Schambra UB, Duncan GE, Breese GR, Fornaretto MG, Caron MG, Fremeau RT Jr (1994) Ontogeny of D1A and D2 dopamine receptor subtypes in rat brain using in situ hybridization and receptor binding. Neuroscience 62:65-85. CrossRef Medline

Schoffelmeer AN, Vanderschuren LJ, De Vries TJ, Hogenboom F, Wardeh G, Mulder AH (2000) Synergistically interacting dopamine D1 and NMDA receptors mediate nonvesicular transporter-dependent GABA release from rat striatal medium spiny neurons. J Neurosci 20:3496-3503. Medline

Skagerberg G, Lindvall O (1985) Organization of diencephalic dopamine neurones projecting to the spinal cord in the rat. Brain Res 342:340-351. CrossRef Medline

Sommer C, Myers RR (1995) Neurotransmitters in the spinal cord dorsal horn in a model of painful neuropathy and in nerve crush. Acta Neuropathol 90:478-485. CrossRef Medline

Svendsen F, Tjølsen A, Hole K (1998) AMPA and NMDA receptordependent spinal LTP after nociceptive tetanic stimulation. Neuroreport 9:1185-1190. CrossRef Medline

Tamae A, Nakatsuka T, Koga K, Kato G, Furue H, Katafuchi T, Yoshimura M (2005) Direct inhibition of substantia gelatinosa neurones in the rat spinal cord by activation of dopamine D2-like receptors. J Physiol 568: 243-253. CrossRef Medline

Taniguchi W, Nakatsuka T, Miyazaki N, Yamada H, Takeda D, Fujita T, Kumamoto E, Yoshida M (2011) In vivo patch-clamp analysis of dopaminergic antinociceptive actions on substantia gelatinosa neurons in the spinal cord. Pain 152:95-105. CrossRef Medline

Terman GW, Eastman CL, Chavkin C (2001) Mu opiates inhibit long-term potentiation induction in the spinal cord slice. J Neurophysiol 85: 485-494. Medline

Todd AJ, Spike RC (1992) Co-localization of Met-enkephalin and somatostatin in the spinal cord of the rat. Neurosci Lett 145:71-74. CrossRef Medline

Todd AJ, Hughes DI, Polgár E, Nagy GG, Mackie M, Ottersen OP, Maxwell DJ (2003) The expression of vesicular glutamate transporters VGLUT1 and VGLUT2 in neurochemically defined axonal populations in the rat spinal cord with emphasis on the dorsal horn. Eur J Neurosci 17:13-27. CrossRef Medline

Tritsch NX, Sabatini BL (2012) Dopaminergic modulation of synaptic transmission in cortex and striatum. Neuron 76:33-50. CrossRef Medline

Trudeau LE, Emery DG, Haydon PG (1996) Direct modulation of the secretory machinery underlies PKA-dependent synaptic facilitation in hippocampal neurons. Neuron 17:789-797. CrossRef Medline

van Dijken H, Dijk J, Voom P, Holstege JC (1996) Localization of dopamine D2 receptor in rat spinal cord identified with immunocytochemistry and in situ hybridization. Eur J Neurosci 8:621-628. CrossRef Medline

Wilkinson SM, Becker WJ, Heine JA (2001) Opiate use to control bowel motility may induce chronic daily headache in patients with migraine. Headache 41:303-309. CrossRef Medline

Williams JT, Ingram SL, Henderson G, Chavkin C, von Zastrow M, Schulz S, Koch T, Evans CJ, Christie MJ (2013) Regulation of $\mu$-opioid receptors: desensitization, phosphorylation, internalization, and tolerance. Pharmacol Rev 65:223-254. CrossRef Medline

Woolf CJ, Salter MW (2000) Neuronal plasticity: increasing the gain in pain. Science 288:1765-1769. CrossRef Medline

Xu M, Moratalla R, Gold LH, Hiroi N, Koob GF, Graybiel AM, Tonegawa S (1994) Dopamine D1 receptor mutant mice are deficient in striatal expression of dynorphin and in dopamine-mediated behavioral responses. Cell 79:729-742. CrossRef Medline

Xu M, Petraschka M, McLaughlin JP, Westenbroek RE, Caron MG, Lefkowitz RJ, Czyzyk TA, Pintar JE, Terman GW, Chavkin C (2004) Neuropathic pain acti- 
vates the endogenous $\kappa$ opioid system in mouse spinal cord and induces opioid receptor tolerance. J Neurosci 24:4576-4584. CrossRef Medline

Yang HW, Zhou LJ, Hu NW, Xin WJ, Liu XG (2005) Activation of spinal $\mathrm{d} 1 / \mathrm{d} 5$ receptors induces late-phase LTP of C-fiber-evoked field potentials in rat spinal dorsal horn. J Neurophysiol 94:961-967. CrossRef Medline

Yang X, Yang HB, Xie QJ, Liu XH, Hu XD (2009) Peripheral inflammation increased the synaptic expression of NMDA receptors in spinal dorsal horn. Pain 144:162-169. CrossRef Medline

Yokoyama C, Okamura H, Nakajima T, Taguchi J, Ibata Y (1994) Autoradiographic distribution of [3H]YM-09151-2, a high-affinity and selective antagonist ligand for the dopamine $\mathrm{D} 2$ receptor group, in the rat brain and spinal cord. J Comp Neurol 344:121-136. CrossRef Medline
Zarrindast MR, Nassiri-Rad S, Pazouki M (1999) Effects of dopaminergic agents on antinociception in formalin test. Gen Pharmacol 32:517-522. CrossRef Medline

Zhao H, Zhu W, Pan T, Xie W, Zhang A, Ondo WG, Le W (2007) Spinal cord dopamine receptor expression and function in mice with 6-OHDA lesion of the A11 nucleus and dietary iron deprivation. J Neurosci Res 85:1065-1076. CrossRef Medline

Zhou LJ, Zhong Y, Ren WJ, Li YY, Zhang T, Liu XG (2008) BDNF induces late-phase LTP of C-fiber evoked field potentials in rat spinal dorsal horn. Exp Neurol 212:507-514. CrossRef Medline

Zhu H, Clemens S, Sawchuk M, Hochman S (2007) Expression and distribution of all dopamine receptor subtypes $\left(D_{1}-D_{5}\right)$ in the mouse lumbar spinal cord: a real-time PCR and non-autoradiographic in situ hybridization study. Neuroscience 149:885-897. CrossRef Medline 